\title{
"Interrelation among Economic Growth, Income Inequality, and Fiscal Performance: Evidence from Anglo-Saxon Countries"
}




\title{
$\mathbb{\Phi}|\mathrm{R}| \mathrm{E}|\mathrm{A}|$
}

Institut de Recerca en Economia Aplicada Regional i Públic

Research Institute of Applied Economics

WEBSITE: www.ub-irea.com•CONTACT: irea@ub.edu

\section{AQR}

\author{
Grup de Recerca Anàlisi Quantitativa Regional \\ Regional Quantitative Analysis Research Group \\ WEBSITE: www.ub.edu/aqr/•CONTACT: aqr@ub.edu
}

\section{Universitat de Barcelona}

Av. Diagonal, $690 \cdot 08034$ Barcelona

The Research Institute of Applied Economics (IREA) in Barcelona was founded in 2005, as a research institute in applied economics. Three consolidated research groups make up the institute: AQR, RISK and GiM, and a large number of members are involved in the Institute. IREA focuses on four priority lines of investigation: (i) the quantitative study of regional and urban economic activity and analysis of regional and local economic policies, (ii) study of public economic activity in markets, particularly in the fields of empirical evaluation of privatization, the regulation and competition in the markets of public services using state of industrial economy, (iii) risk analysis in finance and insurance, and (iv) the development of micro and macro econometrics applied for the analysis of economic activity, particularly for quantitative evaluation of public policies.

IREA Working Papers often represent preliminary work and are circulated to encourage discussion. Citation of such a paper should account for its provisional character. For that reason, IREA Working Papers may not be reproduced or distributed without the written consent of the author. A revised version may be available directly from the author.

Any opinions expressed here are those of the author(s) and not those of IREA. Research published in this series may include views on policy, but the institute itself takes no institutional policy positions. 


\section{Abstract}

The interrelation among economic growth, income inequality, and fiscal performance is very complex. The paper provides the analysis of the interrelations among these variables jointly by the structural VAR methodology, examining also transmission channels among them. This approach allows exploring dynamic interactions among them and feedback effects on each other. The empirical analysis is implemented for the Anglo-Saxon countries, the UK, the USA, and Canada. We find that income inequality has negative effect on economic growth in the case of the UK. The effect is positive in the cases of the USA and Canada. The increase in income inequality worsens fiscal performance for all the countries.

JEL classification: C32, D31, E62, O47

Keywords: economic growth, income inequality, fiscal performance, VAR

Karen Davtyan. AQR Research Group-IREA. Department of Econometrics. University of Barcelona, Av. Diagonal 690, 08034 Barcelona, Spain. E-mail: karen.davtyan@ub.edu

\section{Acknowledgements}

I gratefully acknowledge helpful comments and suggestions from Peter Claeys, Raul Ramos, Enrique Lopez-Bazo, Vicente Royuela, David Castells, and the participants of the AQR-IREA seminar in September, 2013. All remaining errors are mine. 


\section{Introduction}

The recent financial crisis has hit countries and shaken financial systems all over the world. This has led to the implementation of large scale fiscal expansionary interventions and, as a result, to massively increased public debt issuances in the countries. The massive bailouts of the banking system have further burdened fiscal balances and rise considerable concern about fiscal solvency of some countries. Many governments want to keep deficits under control, but rolling back the expansionary measures by cutting spending and raising taxes implies an enormous wealth transfer from tax payers to the financial system. The conduct of expansionary fiscal policies also implies a huge shift in resources among groups which causes worries about growing inequality within countries. Consequently, political instability may follow since people perceive such measures as an unfair redistribution of resources. Moreover, the financial crisis confirms an on-going trend increase in inequality since the early nineties. Increasing inequality within countries has been accompanied by a redistribution of economic resources between developed economies and emerging markets.

Globalization has contributed to reallocation of economic activities to - and increased trade with - emerging economies. The breakthrough of IT in industry has spurred the demand for more highly skilled labor at the cost of blue collar workers (Baldwin and Krugman, 2004). Both trade and technological progress may therefore explain the trend changes in inequality. Rising economic inequality raises concerns about the role of the welfare state in providing a stable environment for making economic decisions by large parts of the population. Growing inequality may undermine political stability. Economic growth could start again to be the engine of social promotion. However, calls for more redistribution can lead to policies that undermine economic progress and deteriorate fiscal performance.

Inequality creates political conflict, and political structures determine the solution for these conflicts. Adequately designed institutions ensure the smooth functioning of economic markets. Political stability improves the long-term outlook and enhances labor and capital productivity and so rises economic growth. With higher economic growth, net gains are positive for all, and political reforms are easier to sustain. This may explain why over time in more egalitarian societies there is less demand for 
redistribution and fiscal performance is better, stimulating greater accumulation of capital and higher growth.

Thus, the interrelations among economic growth, income inequality, and fiscal performance are very complex, which are affected through different channels. Therefore, in this paper we analyze the interrelations among these variables jointly by the structural VAR methodology, examining also transmission channels among them. This approach allows us to explore dynamic interactions among them and feedback effects on each other. The empirical analysis is implemented for the Anglo-Saxon countries, the UK, the USA, and Canada, since the economies of these countries are generally characterized by comparatively low levels of government regulation and high levels of income inequality. Besides, for these countries, there are available relatively long and continuous time series for income inequality. We find that income inequality has negative effect on economic growth in the case of the UK. The effect is positive in the cases of the USA and Canada. The increase in income inequality worsens fiscal performance for all the countries.

The paper is organized as follows. Section 2 discusses interrelations and channels among economic growth, income inequality, and fiscal performance. Section 3 describes empirical modeling and methodology. The description of the data is provided in Section 4. The empirical findings are presented in Section 5, and Section 6 contains concluding remarks and policy implications.

\section{Interrelation among Economic Growth, Income Inequality, and Fiscal Performance}

Since the pioneering contribution by Kuznets (1955), suggesting a non-linear relationship between inequality and growth (inequality first increases and later decreases during the process of economic development, being known as the "Kuznets inverted-U"), there has been a growing interest in analyzing the relationship between both variables (Eicher and Turnovsky, 2003). However, theoretical papers as well as empirical applications have produced controversial results, and economic theory does not have a clear cut answer to the relation between inequality and growth. 
While a considerable part of the literature has shown that inequality is detrimental to growth in the long-run (Alesina and Rodrik, 1994; Clarke, 1995; Perotti, 1996; Persson and Tabellini, 1994), more recent studies (Forbes, 2000; Li and Zou 1998) have challenged this result and found a positive effect of inequality on growth in the shortrun. If one can think that both variables are influenced by the same factors, it is likely to happen that they are mutually caused. The recent meta-analysis by Dominicis et al. (2006) has permitted to conclude that, although policy conclusions are clearly different, probably it is misleading to simply speak of a positive or negative relationship between income inequality and economic growth when looking at the available studies. In the case of the usage of nonparametric estimation methods, Banerjee and Duflo (2000) show that changes in inequality in any direction are associated with subsequent lower growth rates.

Differences in estimation methods, data quality, sample coverage, and the initial level of income are some of the factors that could affect the estimated impact of income inequality on economic growth (Castells-Quintana and Royuela, 2011). The final effect also depends on the way fiscal policy responds to inequality. Political debates evolve around decisions on spending and taxation, the channels of the redistribution of resources, which affect fiscal performance. Depending on the decision about government spending and taxation, fiscal policy has different impact on inequality and growth. Therefore, fiscal policy is an important transmission channel between income inequality and economic growth. In addition to fiscal policy channel, different transmission channels between inequality and growth have been specified in the literature such as capital market imperfections, fertility, domestic market size, saving, and socio-political instability. The validity of the transmission channels and the reduced-form relations between inequality and growth have been empirically tested, using mainly cross-section and panel data (Ehrhart, 2009; Neves and Silva, 2013).

\subsection{Income Inequality and Economic Growth}

In this area of research, one of the mostly studied relations is between income inequality and economic growth. Barro (2000) brings evidence of a negative relationship between inequality and growth for poor countries and a positive relationship for rich countries. 
Analogously, Goav and Moav (2004) argue that while income inequality positively affects economic growth at the stages of physical capital accumulation, later the process is reversed at the stages of human capital accumulation. In addition, it is found out that long-run relation between inequality and growth is negative while the short-run effect of inequality on growth is positive.

Exploring the relation between politics and growth through endogenous growth model, Alesina and Rodrik (1994) find that higher degree of inequality of wealth and income leads to the greater rate of taxation (redistribution) and to the lower economic growth. That is, the more unequal distribution of resources in society leads to lower rate of economic growth, and the link between them is given by redistributive policies. Their empirical results show that inequality in land and income is negatively correlated with subsequent economic growth. They indicate that the important line of research can be the study of dynamic interconnection between income distribution and growth since they are consecutively affect each other.

Alesina and Perotti (1993) explore another transmission channel for the negative relation between income inequality and economic growth. They state income inequality leads to socio-political instability that creates uncertainty in the politico-economic environment, decreasing investment. That is, inequality and investment are negatively related whereas the latter is an important factor for growth. Alesina and Perotti (1993) test their hypotheses, using a bivariate simultaneous equation model in an index of socio-political instability and investment.

Persson and Tabellini (1994) theoretically model that unequal distribution of income in a democratic society produce redistributive economic policies that decrease investment and subsequently economic growth. Their empirical results indicate a negative relation between initial income inequality and subsequent economic growth. Thus, investment could be a link between inequality and growth. Persson and Tabellini (1994) assert that the transmission channel of fiscal policy should also be carefully investigated since government interventions caused by distributional conflicts lead to decrease in investment and consequently to decline in growth. That is, a link between a redistribution policy and economic growth should be further explored as well. 
The study related to the relation between income inequality and economic growth should be done, also taking into account that income inequality consists of inequality of opportunity and inequality of efforts. While inequality of opportunity has negative impact on economic growth, the inequality of efforts leads to economic growth. Since they have different impact on economic growth, the overall effect of income inequality on it depends on what component prevails (Marrero and Rodriguez, 2010). However, to explicitly test it, it is still a challenge because the data on inequality of opportunity are very limited. One of the recent developments in this area is the calculation of Human Opportunity Index by the World Bank (Ferreira, 2012), and it is mainly applied for Latin American countries. With the availability of data on inequality of opportunity, it can be explicitly included in the model and tested its influence on economic growth.

\subsection{Income Inequality and Fiscal Performance}

Economic recessions accompanied with high inequality lead to political pressure, which causes discretionary government spending. The various groups of a country may try to change established inequality through public spending during recessions. Lower income groups demand more transfers while groups with higher incomes want to obtain tax benefits through lighter taxation. The redistribution is influenced by the relative power of each group in the political decision making process Milanovic (1999). In the long run, this conflict can lead to excessive debt if the government pays for these transfers to certain groups without taxing others. In the short term, an economic boom increases government income, making easier to pay more transfers to all groups while in a recession the government with lower disposal income prefers to borrow or raise taxes to ease tensions in the groups.

Larch (2010) argues that fiscal performance is influenced by the different degrees of income inequality. In particular, he shows that countries with higher degree of income inequality are prone to run deficits and accumulate government debt. To explain fiscal performance, Larch (2010) uses econometric analyses with univariate regression models through explanatory variables such as income inequality and economic growth, which is risky since they are not exogenous, and there is a problem of endogeneity, causality between dependent and independent variables. 


\subsection{Fiscal Performance and Economic Growth}

Fiscal performance reflects fiscal policy discipline, and it is significantly affected by the volatility of fiscal policy. As shown by Woo (2011), income inequality leads to the volatility of fiscal policy, which in turn dampens economic growth. That is, he discusses the fiscal policy volatility channel for the negative link between inequality and growth. Woo (2011) considers this channel by separately examining the links between income inequality and fiscal volatility, the latter and growth, and eventually inequality and growth. In the work the negative relation between macroeconomic volatility and growth has also been considered. The studies of the relations between income inequality and economic growth through the fiscal policy volatility channel are conducted by univariate econometric modeling techniques. However, we believe, by studying the isolated relations among them, we miss important information, and we face the endogeneity problem (Woo (2011) tries to address the endogeneity problem through instrumental variables regressions). These concerns are addressed by Muinelo-Gallo and Roca-Sagales (2013) who examine mutually influential relationship between income inequality and economic growth via the fiscal policy channel by considering the systems of structural equations. They employ a system of seemingly unrelated regressions and a simultaneous regression model in their econometric analysis. The systems of structural equations approach to macroeconomic modeling is arguably fundamentally flawed (Green, 2002). In contrast, VARs are generally less ambitions macroeconomic modeling approach that performs as good as or better than structural equation systems for analyzing macroeconomic activity. Ramos and Roca-Sagales (2008), and Roca-Sagales and Sala (2011) employ also VAR modeling approach. However, they mainly focus on the examinations of the fiscal policy effects on GDP while we will directly explore the interrelations among growth, inequality, and fiscal performance.

To show the interrelations among the discussed variables, we draw a diagram, which is presented in Figure 1 in Appendix ${ }^{1}$. From the diagram, we can see the complex mutual interrelations among the variables. Some of the isolated interrelations among them have been extensively studied in the literature. The aim of this paper is to study and analyze those interrelations jointly.

\footnotetext{
${ }^{1}$ All the figures and the tables of the paper are provided in Appendix.
} 


\section{Empirical Modeling and Methodology}

Considering the current state of this research area, we explore the interrelations among economic growth, income inequality, and fiscal performance jointly through structural VAR modeling, taking also into account transmission channels among them. This approach allows us to tackle the endogeneity problem among the variables and to study the considered variables in a system. In addition, it also allows us to examine dynamic interactions among them and feedback effects on each other through impulse response functions and variance decompositions.

\subsection{VAR Models}

In general, a VAR model of order $\mathrm{p}$, denoted VAR(p), can be expressed as:

$$
y_{t}=A_{0}+A_{1} y_{t-1}+A_{2} y_{t-2}+\cdots+A_{p} y_{t-p}+e_{t^{\prime}}
$$

where $y_{t}$ is $(n \times 1)$ vector containing each of the $n$ variables included in the VAR; $A_{0}$ is an $(n \times 1)$ vector of intercept terms; $A_{i}$ are $(n \times n)$ matrices of coefficients; and $e_{t}$ is an $(n \times 1)$ vector of error terms. Nevertheless, any $\operatorname{VAR}(\mathrm{p})$ can be rewritten as a $\operatorname{VAR}(1)$, which is known as the companion form of the VAR(p).

It is assumed that the vector of error terms is a n-dimensional white noise process, i.e., $E\left(e_{t}\right)=0, E\left(e_{t} e_{t}^{\prime}\right)=\Omega$, and $E\left(e_{t} e_{s}^{\prime}\right)=0$ for $s \neq t$, where $\Omega$ is a $(n \times n)$ symmetric positive definite matrix. Since error terms are serially uncorrelated with constant variances and the right hand side of the $\operatorname{VAR}(\mathrm{p})$ equation (1) contains only predetermined variables, each equation in the system can be estimated by OLS. Moreover, these estimates are consistent and asymptotically efficient (Enders, 1995). This is true not only in the case of stationary variables, but also in the case when some variables are integrated (Sims et al., 1990). Based on this, some researchers estimate VAR models in levels ignoring nonstationarity issues. A drawback of this approach is that, while the autoregressive coefficients are estimated consistently, this may not be true for other quantities derived from these estimates (Kamps, 2005).Especially, Phillips (1998) shows that impulse responses and forecast error variance decompositions based on the estimation of unrestricted VAR models are inconsistent at long horizons in the presence of nonstationary variables. Impulse response analysis is one of the main tools 
for policy analysis in the case of VAR models and it is widely used in the paper. Therefore, we employ only stationary series for estimations in the current research work.

\subsection{Structural VAR Models}

Little can be learned about the underlying economic structure of the aforementioned VAR models in their standard forms unless identifying restrictions are imposed since these models are reduced form models. The shocks of this reduced form model are not generally economically meaningful because they are linear combinations of structural shocks. The underlying structural model is obtained by pre-multiplying both sides of the unrestricted VAR by the $(n \times n) B$ matrix:

$$
B y_{t}=\Gamma_{0}+\Gamma_{1} y_{t-1}+\Gamma_{2} y_{t-2}+\cdots+\Gamma_{p} y_{t-p}+\varepsilon_{t} \text {, }
$$

where $\Gamma_{\mathrm{i}}=\mathrm{BA}_{\mathrm{i}}$ for $\mathrm{i}=0, \ldots, \mathrm{p}$ and $\varepsilon_{\mathrm{t}}=\mathrm{Be}_{\mathrm{t}}$, which describes the relation between the structural disturbances $\varepsilon_{\mathrm{t}}$ and the reduced form disturbances $e_{\mathrm{t}}$ (or equivalently $\mathrm{e}_{\mathrm{t}}=\mathrm{B}^{-1} \varepsilon_{\mathrm{t}}$ ). It is assumed that the structural disturbances $\varepsilon_{\mathrm{t}}$ are white noise and uncorrelated with each other, i.e., their variance-covariance matrix is diagonal. The matrix $B$ describes the contemporaneous relation among the variables contained in the vector $y_{t}$. That is, there are more parameters in the structural model (2) than in the reduced form VAR presented in (1). Therefore, without restrictions on the parameters of the structural model, it is not identified. There are number of alternative identification procedures proposed in the literature. In this empirical work, we apply the widely used recursive approach originally proposed by Sims (1980) that restricts B (and correspondingly $\mathrm{B}^{-1}$ ) to a lower triangular matrix. That is, this identification scheme, also known as Cholesky decomposition, imposes a recursive causal structure from the top variables to the bottom variables. While this recursive approach enables to uniquely identify the structural VAR model, it has $n$ ! possible orderings in total. Though economic reasoning usually allows selecting an appropriate ordering, the sensitivity of the dynamic properties of the model to alternative orderings of the variables should be checked. 


\subsection{Impulse Response Functions}

Impulse response functions (IRFs) are intuitive tools to analyze interactions among variables in VAR models. To see this and keep things simple, we can consider the case of $\operatorname{VAR}(1)$ without loss of generality since any $\operatorname{VAR}(p)$ can be rewritten as a VAR(1). Firstly we need to express it in its vector moving average (VMA) representation by using recursive substitution:

$$
y_{t}=A_{0}+\sum_{i=0}^{\infty} A_{1}^{i} e_{t-i}
$$

To trace the economic impact of an impulse to one of the variables on itself and on the rest of the variables in the system, it is required the VMA representation based on the orthogonal structural shocks instead of the reduced form disturbances, which are correlated with each other. Therefore, by using the expression for the reduced form disturbances $e_{t}$, we rewrite (3) as:

$$
y_{t}=A_{0}+\sum_{i=0}^{\infty} A_{1}^{i} B^{-1} \varepsilon_{t-i}
$$

It can be written in a more compact form as:

$$
y_{t}=A_{0}+\sum_{i=0}^{\infty} \Phi_{i} \varepsilon_{t-i}
$$

By updating this equation, we get the responses of $y_{t+i}$ to one unit impulse at timet. If we graph each element of $\Phi_{i}$ against $i$ periods, we obtain the response of each variable in the system from the impulse to the different structural shocks. Thus, IRFs describe how the VAR system reacts over time to one unit shock in a variable assuming that there is no other shock in the system during that period.

\subsection{Variance Decomposition}

Another type of analysis which is usually done with structural VAR models is the variance decomposition. It allows decomposing the total variance of a time series into the percentages attributable to structural shocks, which are orthogonal and have unit 
variances. As discussed above, an identified structural VAR can be expressed through the VMA representation:

$$
y_{t}=A_{0}+F(L) \varepsilon_{t}
$$

where $F(l)$ is a polynomial in lag operators. The variance of $y_{i t}$ is given by

$$
\operatorname{Var}\left(y_{i t}\right)=\sum_{k=1}^{n} \sum_{j=0}^{\infty} F_{i k}^{j^{2}} \operatorname{Var}\left(\varepsilon_{k t}\right)=\sum_{k=1}^{n} \sum_{j=0}^{\infty} F_{i k}^{j^{2}},
$$

where $\sum_{j=0}^{\infty} F_{i k}^{j^{2}}$ is the variance of $y_{i t}$ generated by the $k$ th shock. This implies that

$$
\frac{\sum_{j=0}^{\infty} F_{i k}^{j^{2}}}{\sum_{k=1}^{n} \sum_{j=0}^{\infty} F_{i k}^{j^{2}}}
$$

is the percentage of the variance of $y_{i t}$ explained by the $k$ th shock. It is also possible to study the variance of a variable explained by a structural shock at a given horizon. The percentage of the variance of $y_{i t}$ due to the $k$ th shock at horizon $h$ is given by

$$
\frac{\sum_{j=0}^{h-1} F_{i k}^{j^{2}}}{\sum_{k=1}^{n} \sum_{j=0}^{h-1} F_{i k}^{j^{2}}}
$$

Thus, the variance decomposition analysis enables to decompose the total variance of a time series into the percentages attributable to each structural shock.

\section{Data}

\subsection{The Choice of the Countries}

The empirical analysis is implemented for the Anglo-Saxon countries, the UK, the USA, and Canada. The economies of these countries are generally characterized by the low levels of the government regulation, the small shares of the public sector, and by free markets. While the Anglo-Saxon economic model might foster innovations and competitive advantages, stimulating growth and creating jobs in a country, its impact on the overall prosperity in the society is debatable. In particular, it is asserted that this 
economic model is less redistributive and leads to higher income inequality and poverty in Anglo-Saxon countries compared to other developed countries that employ other economic models such as Nordic and Continental European models. In this regard, it is very interesting to explore the interrelations among economic growth, income inequality, and fiscal performance for these Anglo-Saxon countries.

The UK, the USA, and Canada are relatively homogeneous and similar in backgrounds (Atkinson and Leigh, 2013) but they have their specific features. Especially, the UK has comparatively higher level of taxation and it spends relatively more on the welfare state. Besides, the UK has adopted some social programs used within European continental economic models (Putten, 2005).

The choice of the countries considered in the paper is also conditioned by the availability of the data on income inequality. They have relatively long and continuous time series for income inequality. This is very important because scarcity and diversity of the data on income inequality are one of the major difficulties for empirical analyses in this research area. First of all, income inequality datasets generally are not fully available for considered periods and shorter than time series usually used in macroeconomic analyses (e.g., for economic growth). In addition, income inequality can be measured based on gross or net (disposable) income, and the unit of measurement can be an individual or a household. Therefore, it is expectable to get quite different measures of income inequality, depending on which of these classifications are used. Emphasizing this, Knowles (2001) stresses the importance of the usage of consistently measured inequality data.

Due to lack of comparable inequality data, many researchers have to mix different classifications of data together. However, Knowles (2001) argues that this is inappropriate and shows that the empirical results found in these cases are not robust. He also points out that the estimates in the cross-country analysis on inequality and growth are highly sensitive to the sample of countries included. In addition, data on inequality usually come from different sources, and they are not automatically comparable since differences in underlying survey methodologies might impair the comparability. Taking all these arguments into account, in the paper we try to use the longest possible consistently measured comparable data on income inequality on a 
country basis. Depending on their availability, we accordingly select the same ranges for the other time series used in the empirical analysis.

\subsection{Dataset}

All the data are annual and range over the period from 1960 to 2010.As an income inequality measure, we use Gini coefficient (GINI) in our empirical analysis since it provides the broadest coverage across time and countries. Gini coefficients are taken from UNU-WIDER World Income Inequality Database, Version 2.0c, May, 2008, OECD, and Eurostat databases. We use these sources for Gini coefficients because by far they have the most comprehensive set of income inequality data. In a case when a value of a Gini coefficient is missing from a series, its trend is taken (the arithmetic average of the previous and next values). When we have to combine income inequality data of the same classification but from different sources, we adjust (shift) shorter time series towards the longer ones. We use inequality data based on disposable income, which are the most appropriate to use in empirical analyses as argued by Knowles (2001). Besides, they are mainly the longest available series of income inequality data.

Data on economic growth (GRGDP) are taken from the World Development Indicators of the WB. The time series for economic growth are annual chained indices. Investment (KI) and government spending (KG) shares of GDP are from the Penn World Table (version 7.1). Tax revenue as a percentage of GDP (TAXES) is from Federal Reserve Bank of St. Louis (FRED) and OECD. Government net lending/borrowing as a percentage of GDP (NLB) is from FRED, OECD, and Eurostat. The detailed definitions of the variables are provided in Table 1, and the general statistical characteristics of the variables are presented in Table 2 .

\subsection{Stationary Transformation}

The time series of the variables (except for economic growth) are not stationary according to the results of the augmented Dickey-Fuller test. We make stationary transformation for the time series before using them in the empirical analysis. Two common ways of stationary transformation are differencing and detrending. Depending on whether a series is difference or trend stationary, the appropriate method is applied. 
One of the widely used detrending methods is Hodrick-Prescott (HP) filter ${ }^{2}$ (Hodrick and Prescott, 1997), which is a smoothing method to obtain a long-term trend component of a series. The HP filter also renders stationary time series that are difference stationary and integrated of higher order (King and Rebelo, 1993). Taking also into account that all the variables are relative quantities, we detrend the series by the HP filter to also provide economic meaning to the variables after their stationary transformation.

For the ratio variables, the detrending is implemented by subtracting the HP filter from the actual series. These detrended series show percentage points deviations from their long-term means. Besides, these variables are initially given at a point in time in contrast to economic growth, which relates to a previous period. Therefore, to provide maximal comparability for all of the data for the empirical analysis, the index for economic growth is first brought to base (to its starting value for each of the series). That results in the nonstationary series. Then, it is also detrended by the HP filter. For the base index of economic growth, detrending is carried out by dividing the series by the HP filter and subtracting one (all this expression is also multiplied by 100). In this case, the detrended series show percentage deviations from their long-term means.

\section{Empirical Results}

For each country, the interrelation among economic growth, income inequality, and fiscal performance, measured by government net lending/borrowing, are examined by the structural VAR methodology. Our VAR specification approach is conditioned on a compromise between a parsimonious model and the one that does not have omitted variable bias. Therefore, we consider benchmark and extended VAR specifications. The benchmark specification that is the most parsimonious and basic one includes economic growth, income inequality, and fiscal performance (GRGDP, GINI, NLB). The extended model also allows exploring transmission channels among them, and it additionally contains government spending, investment, and taxes (KG, KI, GRGDP, GINI, TAXES, NLB).

2 The usage of the Hodrick-Prescott filter can be found, for example, in the works by Ball and Mankiw (2002), Juillard et al. (2005), and Pytlarczyk (2005). 
Taking into account the results of the information criteria and the limitations of the available time series, we use first-order VAR models, which are estimated by OLS. The dynamic interrelations among the variables are studied by the IRFs (ordinary and accumulated) and variance decompositions. As described in Section 3, the structural shocks, which are considered as one-standard deviations to the variables, are recovered and they get their natural economic meaning. They are identified by the Cholesky decomposition, which requires to impose the ordering of the variables that describes the contemporaneous relations among them. Thus, we need to specify the ordering of the variables that has economic reasoning behind it.

\subsection{Benchmark Specification}

For the benchmark specification (GRGDP, GINI, NLB), it is natural to assume that contemporaneously government net lending/borrowing does not impact economic growth and income inequality but it is affected by them. The contemporaneous impact of economic growth is not usually distributionally neutral and it affects income inequality. On the other hand, growth likely responds to changes in inequality only in the long term due to the considerable transmission mechanisms, such as capital accumulation (Benabou, 1996, Perotti, 1996, Ramos and Roca-Sagales, 2008). That is, economic growth should come first in the model. In any case, we also estimate the VAR model and compute IRFs with the reverse order of growth and inequality, but the results do not change significantly. Thus, the ordering of the variables for the basic VAR model is as follows: GRGDP, GINI, NLB.

From the IRFs presented in Figure 2, we can see that the structural shock of one standard deviation ${ }^{3}$ in economic growth leads to 0.1 percentage points increase in income inequality in the case of the UK and to around 0.6 and 0.8 percentage points declines in income inequality in the cases of the USA and Canada respectively. The shock in economic growth results in the rises of government net lending/borrowing by approximately $0.7,1.1$, and 1.2 percentage points for the UK, the USA, and Canada respectively. While the positive effect of the growth increase on government net lending/borrowing is expectable because of the anticipated rise in government revenues,

\footnotetext{
${ }^{3}$ As described in Subsection 4.3, all deviations and changes in the variables (after their stationary transformation) are in relation to their long-term means.
} 
the effect of the growth shock on inequality is not unambiguous as indicated by the results ${ }^{4}$.

It would not be correct to view the IRFs of inequality to the growth shock in the countries through the concept of the Kuznets curve. That would require observing the relation between growth and inequality in a country for a longer term. Instead, we interpret these IRFs through the disaggregation of economic growth. Based on the production function, economic growth could be generally attributable to the growth in technology, capital, and labor. So, the impact of the growth shock on inequality could depend on the structure of the increase in labor that contributes to the economic growth. For instance, if the increased labor consists of many people with low level of income, it can reduce inequality due to the earnings of these employees. Thus, for the considered countries, the differences in the IRfs of inequality to the growth shock might be due to the distinct structures in their labor increases.

As can be observed from Figure 3 and Table 3, a structural shock to income inequality induces to the decline in economic growth (by accumulated 0.2 percent over two periods) for the UK and to the increases in growth (by accumulated 0.3 percent over two periods) for the USA and Canada. These results underline that the relation between inequality and growth is not definite and that is outlined in the literature. The negative effect of inequality on growth is asserted in the works such as Alesina and Rodrik (1994) and Persson and Tabellini (1994). The positive effect of inequality on growth for the USA and Canada is in line with Barro's (2000) evidence that this relationship is positive for developed countries. In particular, Partridge (2005) shows that inequality are positively related to long run growth in the USA, and that is in line with our empirical results, which are obtained for the comparatively long time period. The differences in these effects for the Anglo-Saxon countries could be explained by the distinctions between the UK and Anglo-American economic models. In particular, the former probably shares some common features with European continental economic models and spends relatively more on the welfare state.

From Figure 3 and Table 3, we can also see that the rise in inequality generally leads to the reduction of government net lending/borrowing in all the countries. In particular,

\footnotetext{
${ }^{4}$ The accumulated responses over 2,5 , and 10 periods are presented in the tables after the ordinary IRFs.
} 
over two periods it leads to accumulated $0.3,0.04$, and 0.1 percentage points reductions in the UK, the USA ${ }^{5}$, and Canada respectively. These results are congruent with Larch's (2010) work on the negative effect of income inequality on fiscal performance.

In the case of the variance decomposition analysis, the results for all the countries are actually the same (Figures 4-6). The variations of economic growth are not generally explained by structural shocks to income inequality and government net lending/borrowing. The variance of inequality is a bit more explained by a shock to economic growth (around 15 percent in the cases of the UK and the USA). The variations in government net lending/borrowing are significantly related to shocks to economic growth (about 20 percent for the UK and 60 percent for the USA and Canada) while its variation is also influenced by a shock to inequality in the case of the UK (approximately 15 percent).

In general, the estimation results for the baseline VAR model are not very significant, and they indicate that there are other variables that influence the dynamics and interrelations among economic growth, income inequality, and fiscal performance. Therefore, we extend the VAR model by the other variables and we implement the empirical analysis also with it.

\subsection{Extended Specification}

For the ordering of the variables in the case of the extended VAR model, we mainly follow Ramos and Roca-Sagales (2008) since they use a similar VAR model. In addition to the considered variables, we also include government spending, investment, and taxes in the model. As in the basic case, it is still reasonable to assume that contemporaneously government net lending/borrowing does not influence the considered variables but it is affected by them. Contemporaneously investment impact economic growth (Alesina and Perotti, 1993) and consequently the other variables except of government spending, which is planned in advance. Thus, the extended VAR model has the following ordering of the variables: KG, KI, GRGDP, GINI, TAXES, NLB.

\footnotetext{
${ }^{5}$ This result is more obvious for the USA in the case of the extended VAR model.
} 
In the cases of shocks to economic growth and income inequality, the IRFs of the extended model have almost the same results as in the benchmark scenario (these estimation results are available on request). Therefore, we only provide the IRFs in the cases of shocks to government spending, investment, and taxes. The IRFs in the cases of the growth and inequality shocks are available on request.

From Figure 7, we can see that a government spending shock decreases economic growth by around 1.0, 1.2, and 1.4 percent in the UK, the USA, and Canada respectively. That is, we observe the crowding out effect for all the countries. As can be seen from Table 4, over two periods the government spending shock decreases income inequality by accumulated 0.05 percentage points in the UK but it raises inequality by accumulated 0.16 and 0.04 percentage points in the USA and Canada. This result for the UK corroborates the corresponding finding provided by Ramos and Roca-Sagales (2008). The results for the USA and Canada indicate that government spending does not necessarily decrease income inequality since government spending does not include transfer payments that specifically directed for the reduction of inequality. However, the government spending shock, as expected, reduces government net lending/borrowing in all the countries. Especially, as we can notice from Figure 7, it reduces government net lending/borrowing by around $0.7,0.8$, and 1.0 percentage points in the UK, the USA, and Canada respectively.

From Figure 8, we can observe that an investment shock boosts economic growth by approximately $1.3,1.0$, and 0.5 percent in the UK, the USA, and Canada respectively. It raises inequality by nearly 0.05 percentage points in the UK but decreases inequality by around 0.05 and 0.1 percentage points in the USA and Canada. The investment shock leads to about $0.6,0.7$, and 0.4 percentage points rises in government net lending/borrowing in the UK, the USA, and Canada respectively. The economic interpretations of these effects of the investment shock are similar to the explanation of the impacts of the growth shock due to the direct positive effect of investment on economic growth.

As can be seen from Table 6, over two periods a shock to taxes increases economic growth by accumulated 0.2 percent in the UK but it reduces growth by accumulated 0.3 and 0.4 percent in the USA and Canada. Since taxes include direct as well as indirect 
taxes, the relation between growth and taxes is not definite as it is indicated by the results. Over two periods the shock to taxes raises income inequality by $0.01,0.01$, and 0.09 percentage points in the UK, the USA, and Canada respectively. That is, the effect of indirect (consumption) taxes, which increases inequality (mainly through VAT), prevails over the impact of the usually progressive direct taxes, which generally reduce inequality. From Figure 9, we can see that the shock to taxes increases government net lending/borrowing by approximately $0.9,0.5$, and 0.2 percentage points in the UK, the USA, and Canada respectively. As expected, the shock to taxes generally increases government net lending/borrowing in the countries.

For the extended VAR model, the variance decompositions for growth, inequality, and fiscal performance due to the structural shocks to these variables follow the similar patterns for all the countries (Figures 10-12) as in the benchmark scenario. In addition, the variance of economic growth is significantly influenced by a shock to investment (around 40, 30, and 20 percent in the cases of the UK, the USA, and Canada respectively). This is also the case with a shock to government spending (approximately20, 40, and 50 percent for the UK, the USA, and Canada respectively). The government spending shock also substantially affects the variations in government net lending/borrowing (about 25, 40, and 55 percent for the UK, the USA, and Canada respectively). In the case of the UK, the variance of government net lending/borrowing is considerably attributable to a shock to taxes too (around 35 percent).

\subsection{Robustness Check}

We also implement the robustness check for the estimation results. We carry out it for the IRFs in three dimensions. First of all, we try some other alternative orderings for the contemporaneous relations among the variables. Then, we use different samples for the empirical analysis by using rolling and recursive schemes, and by just excluding the last parts of the sample periods since the financial crisis of 2008. Finally, we implement the analysis by generalized impulse response functions (Pesaran and Shin, 1998). In all the cases, the results do not significantly change. These results of the robustness check are available upon request. 


\section{Conclusion}

The empirical analysis for the Anglo-Saxon countries reveals that there are generally some differences in the obtained results for the UK, and the USA and Canada. This could be explained by the differences between the UK and the Anglo-American economic models. With comparatively higher level of taxation and spending on the welfare state, the UK probably shares some common features with European continental economic models. In particular, income inequality has negative effect on economic growth in the case of the UK. The effect is positive in the cases of the USA and Canada. Income inequality generally reduces government net lending/borrowing for all the countries. Economic growth leads to the increase of income inequality in the case of the UK and to the decline of inequality in the cases of the USA and Canada. At the same time, economic growth improves government net lending/borrowing in all the countries. Government spending leads to the decline in inequality in the UK but to its increase in the USA and Canada. In addition, government spending reduces growth through crowding out and worsens fiscal performance in all the countries. Consequently, government should be careful with its spending policies planned for the reduction of inequality. An increase in tax revenues raises income inequality in all the considered countries. Taking into account that taxes include direct taxation, which generally reduces inequality, and indirect taxation, which increases inequality, we can infer that the effect of indirect taxation outweighs. Therefore, government should also consider this effect of the increased taxation for the design of its fiscal policies. 


\section{References}

- Alesina, A. and Perotti, R. (1993), "Income Distribution, Political Instability, and Investment", NBER Working Paper No. 4486.

- Alesina, A. and Rodrik, D. (1994), "Distributive Politics and Economic Growth", The Quarterly Journal of Economics, 109, pp. 465-490.

- Atkinson, A. and Leigh, A. (2013), “The Distribution of Top Incomes in Five Anglo-Saxon Countries Over the Long Run", Economic Society of Australia, Economic Record, March, pp. 1-17

- Baldwin, R. and Krugman, P. (2004), "Agglomeration, Integration and Tax Harmonization”, European Economic Review, vol. 48(1), pp. 1-23.

- Ball, L. and Mankiw, G. (2002), "The NAIRU in Theory and Practice”, Journal of Economic Perspectives, Volume 16, Number 4, pp. 115-136.

- Banerjee, A. and Duflo, E. (2000), "Inequality and Growth: What can the data say?", NBER Working Paper No. 7793.

- Barro, R. J. (2000), "Inequality and Growth in a Panel of Countries", Journal of Economic Growth, 5, pp. 5-32.

- Benabou, R. (1996), “Inequality and Growth”, NBER Working Paper 5658.

- Castells-Quintana, D. and Royuela, V. (2011),“Agglomeration, Inequality and Economic Growth", IREA-WP series, No. 2011/14.

- Clarke, G. (1995), "More Evidence on Income Distribution and Growth", Journal of Development Economics, 47, pp. 403-427.

- Dominicis, L., Groot H., and Florax, R. (2006), "Growth and Inequality: A Meta-Analysis," Tinbergen Institute Discussion Papers 06-064/3, Tinbergen Institute.

- Ehrhart, C. (2009), "The effects of inequality on growth: a survey of the theoretical and empirical literature”, ECINEQ WP2009-107.

- Eicher, T. and Turnovsky S. (2003) "Growth and Inequality: Issues and Policy Implications", Cambridge MA, MIT Press. 
- Enders, W. (1995), “Applied Econometric Time Series”, Iowa State University, John Wiley \& Sons, Inc.

- Ferreira, F. (2012), "Inequality of Opportunity Around the World: What Do We Know So Far?", Inequality in Focus, The World Bank, Volume 1 Number 1, April, pp. 8-11.

- Forbes, K. (2000), “A Reassessment of the Relationship between Inequality and Growth", The American Economic Review 90 (4), pp. 869-887.

- Forni, M. and Gambetti, L. (2011), "Testing for Sufficient Information in Structural VARs,” Barcelona GSE Working Paper No. 536.

- Galor, O. and Moav, O. (2004), "From Physical to Human Capital Accumulation: Inequality and the Process of Development", Review of Economic Studies 71, pp. 1001-1026.

- Green, W. (2002), "Econometric Analysis”, Fifth Edition, New York University, Prentice Hall, pp. 586-587.

- Heston, A., Summers R., and Aten, B. "Penn World Table Version 6.2”, Center for International Comparisons of Production, Income and Prices at the University of Pennsylvania, September 2006.

- Hodrick, R. and Prescott, E. (1997), "Postwar US Business Cycles: An Empirical Investigation," Journal of Money, Credit, and Banking, 29 (1), pp. 116.

- Juillard, M., Karam, P., Laxton, D. and Pesenti, P. (2004), "Welfare-Based Monetary Policy Rules in an Estimated DSGE Model of the US Economy", Federal Reserve Bank of New York, NBER and CEPR.

- Kamps, C. (2005), “The dynamic effects of public capital: VAR evidence for 22 OECD countries”, International Tax and Public Finance, vol. 12, pp. 533-58.

- King, R. and Rebelo, S. (1993), "Low Frequency Filtering and Real Business Cycles”, Journal of Economic Dynamics and Control, Vol, 17, No. 1-2.

- Knowles, S. (2001), "Inequality and Economic Growth: The Empirical relationship Reconsidered in the Light of Comparable Data", CREDIT Research Paper, Number 01/03, March, pp. 1-28. 
- Kuznets, S. (1955), "Economic Growth and Income Inequality", American Economic Review 45, pp. 1-28.

- Larch, M. (2010), "Fiscal Performance and Income Inequality: Are Unequal Societies More Deficit-Prone? Some Cross-Country Evidence", European Economy, Economic Papers 414.

- Li, H. and Zou, H. (1998), "Income inequality is not harmful for growth: theory and evidence", Review of Development Economics 2 (3), pp. 318-334.

- Marrero, G. and Rodriguez, J. (2010), “Inequality of Opportunity and Growth”, ECINEQ WP 2010 -154, February.

- Milanovic, B. (1999), "Do more unequal countries redistribute more? Does the median voter hypothesis hold?", World Bank Policy Research Working Paper No 2264, December.

- Muinelo-Gallo, L. and Roca-Sagales, O. (2011), "Economic Growth \& Inequality: the Role of Fiscal Policies", UAB, Document de Treball No. 11.05.

- Muinelo-Gallo, L. and Roca-Sagales, O. (2013), "Joint determinants of fiscal policy, income inequality and economic growth", Economic Modeling 30, pp. 814-824.

- Neves, P.C., and Silva, S.M.T. (2013), "Survey Article: Inequality and Growth: Uncovering the Main Conclusions from the Empirics", Journal of Development Studies, DOI:10.1080/00220388.2013.841885, pp. 1-21.

- Partridge, M. (2005), "Does income distribution affect U.S. state economic growth?”, Journal of Regional Science 45, pp.363-394.

- Perotti, R. (1996), "Growth, Income Distribution and Democracy: What the Data Say?", Journal of Economic Growth 1, pp. 149-187.

- Persson, T. and Tabellini, G. (1994), “Is Inequality Harmful for Growth?”, Theory and Evidence, American Economic Review, 84, pp. 600-621.

- Pesaran, M. H. and Y. Shin (1998), “Generalized Impulse Response Analysis in Linear Multivariate Models", Economics Letters, 58, pp. 17-29. 
- Phillips, P. (1998), “Impulse Response and Forecast Error Variance Asymptotics in Nonstationary VARs", Journal of Econometrics 83 (1-2), pp. 21-56.

- Putten, R. (2005), “The Anglo-Saxon Model: a Critical View”, BNP Paribas, Conjoncture, October, pp. 16-27.

- Pytlarczyk, E. (2005), “An estimated DSGE model for the German economy within the euro area", Deutsche Bundesbank, Discussion Paper, Series 1: Economic Studies, No 33/2005.

- Ramos, X. and Roca-Sagales, O. (2008), "Long-Term Effects of Fiscal Policy on the Size and Distribution of the Pie in the UK", Fiscal Studies, Vol. 29, No. 3, pp. 387-411.

- Roca-Sagales, O. and Sala, H. (2011), "Government Expenditures and the Growth-Inequality Trade-Off: The Swedish Case", Journal of Income Distribution, pp. 38-54.

- Sims, C. (1980), “Macroeconomics and Reality”, Econometrica 48 (1), pp. 1-48.

- Sims, C., Stock, J. and Watson M. (1990), "Inference in Linear Time Series Models with Some Unit Roots", Econometrica58 (1), pp. 113-144.

- Woo, J. (2011), "Growth, income distribution, and fiscal policy volatility", Journal of Development Economics 96, pp. 289-313. 


\section{Appendix}

Figure 1: Interrelations among the Variables

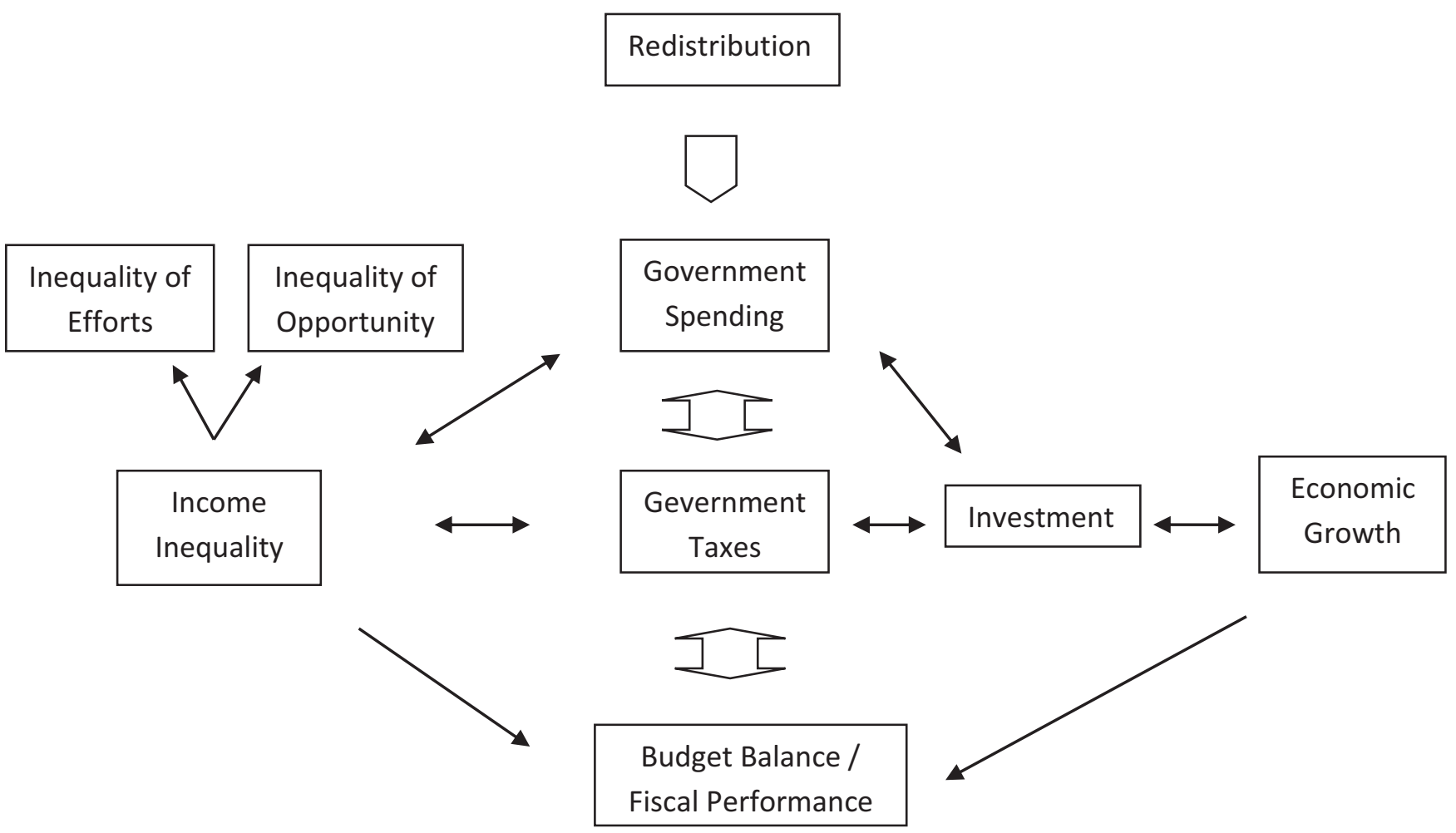


Table 1: The List of Abbreviations and Their Detailed Definitions

\begin{tabular}{|c|l|}
\hline Abbreviation & \multicolumn{1}{c|}{ Definition } \\
\hline GINI & Gini coefficient of disposable income inequality \\
\hline GRGDP & $\begin{array}{l}\text { Annual percentage growth rate of GDP at market prices based on } \\
\text { constant local currency. Aggregates are based on constant 2000 } \\
\text { U.S. dollars. }\end{array}$ \\
\hline KI & $\begin{array}{l}\text { Investment share of PPP converted GDP per capita at 2005 } \\
\text { constant prices }\end{array}$ \\
\hline KG & $\begin{array}{l}\text { Government consumption share of PPP converted GDP per capita } \\
\text { at 2005 constant prices }\end{array}$ \\
\hline TAXES & Total tax revenue as percentage of GDP \\
\hline NLB & General government net lending/ borrowing as percentage of GDP \\
\hline
\end{tabular}

Table 2: The General Statistical Characteristics of the Initial Variables

\begin{tabular}{|c|c|c|c|c|c|c|c|c|c|c|c|c|c|}
\hline \multicolumn{14}{|c|}{ Aggregate Indices for the Observed Initial Series } \\
\hline & & \multicolumn{2}{|c|}{ GINI } & \multicolumn{2}{|c|}{ GRGDP } & \multicolumn{2}{|c|}{$\mathrm{KG}$} & \multicolumn{2}{|c|}{$\mathrm{KI}$} & \multicolumn{2}{|c|}{ TAXES } & \multicolumn{2}{|c|}{ NLB } \\
\hline Countries & Range & Mean & SD & Mean & $\mathrm{SD}$ & Mean & SD & Mean & SD & Mean & $\mathrm{SD}$ & Mean & SD \\
\hline UK & $\begin{array}{l}1970- \\
2010\end{array}$ & 30.32 & 4.42 & 2.37 & 2.32 & 8.52 & 1.25 & 17.17 & 1.39 & 34.99 & 1.57 & -3.07 & 3.00 \\
\hline USA & $\begin{array}{l}1960- \\
2010\end{array}$ & 34.04 & 2.43 & 3.14 & 2.24 & 9.15 & 2.27 & 19.94 & 2.46 & 19.98 & 1.12 & -4.34 & 2.40 \\
\hline Canada & $\begin{array}{l}1976- \\
2010\end{array}$ & 30.11 & 1.36 & 2.72 & 2.15 & 6.99 & 0.60 & 20.95 & 2.56 & 33.71 & 1.92 & -3.48 & 3.63 \\
\hline
\end{tabular}




\section{The Benchmark VAR Model}

\section{Figure 2: IRFs to a Shock to Economic Growth}

\section{The UK}

Responsesto a Cholesky One S.D. Innovation to GRGDP \pm 2 S.E.

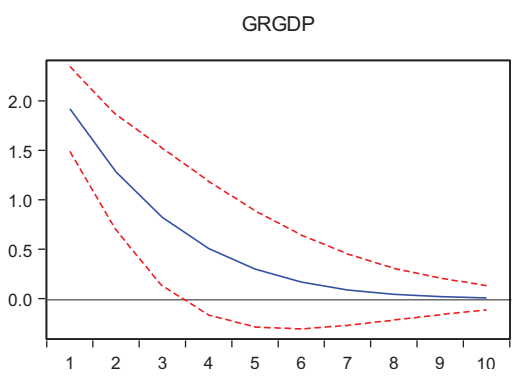

GIN

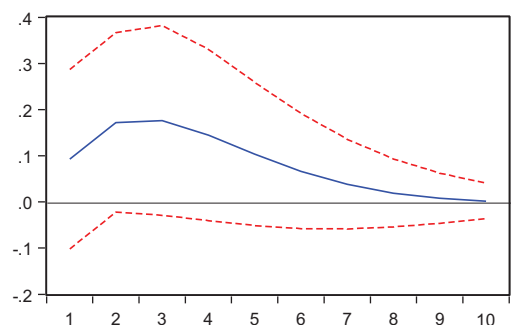

NLB

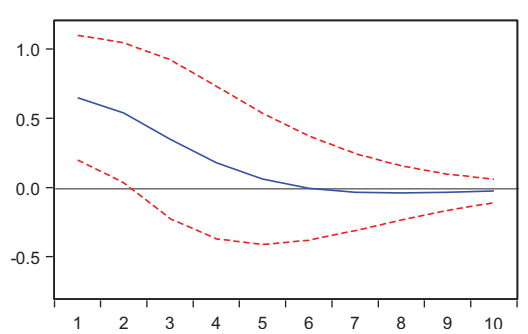

The USA

Responsesto a Cholesky One S.D. Innovation to GRGDP \pm 2 S.E.

GRGDP

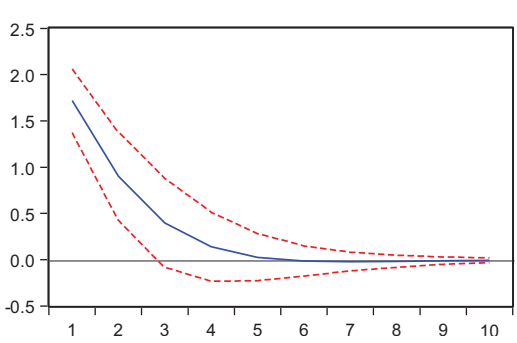

GIN

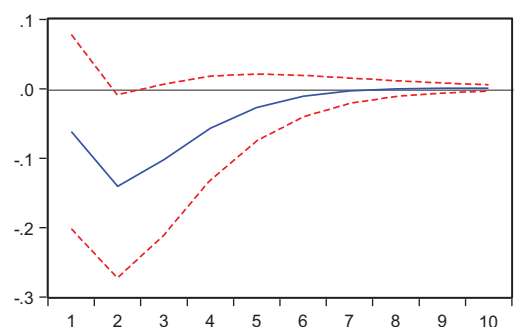

NLB

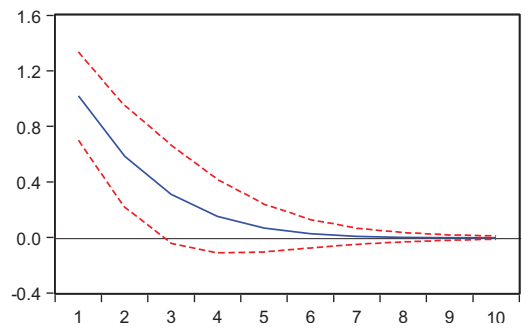

Canada

Responsesto a Cholesky One S.D. Innovation to GRGDP \pm 2 S.E.
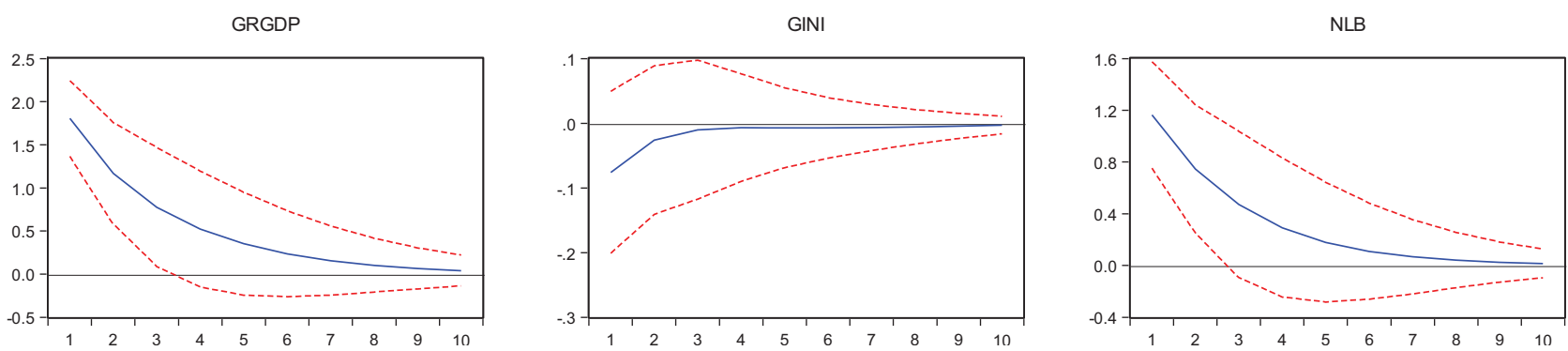
Table 3: Accumulated IRFs to a Shock to Economic Growth

The UK

\begin{tabular}{cccc}
\hline \hline Period & GRGDP & GINI & NLB \\
\hline \hline \multirow{2}{*}{2} & 3.200701 & 0.264858 & 1.185550 \\
& $(0.43834)$ & $(0.16874)$ & $(0.42286)$ \\
5 & 4.830167 & 0.688883 & 1.771673 \\
& $(1.31327)$ & $(0.37642)$ & $(1.08221)$ \\
10 & 5.158918 & 0.821640 & 1.629044 \\
& $(1.92641)$ & $(0.48047)$ & $(1.45428)$ \\
\hline \hline
\end{tabular}

Note: Standard errors are in parentheses

The USA

\begin{tabular}{cccc}
\hline \hline Period & GRGDP & \multicolumn{1}{c}{ GINI } & \multicolumn{1}{l}{ NLB } \\
\hline \hline \multirow{2}{*}{2} & 2.619003 & -0.202523 & 1.602130 \\
& $(0.34213)$ & $(0.10866)$ & $(0.28826)$ \\
5 & 3.180008 & -0.388570 & 2.129118 \\
& $(0.80303)$ & $(0.18628)$ & $(0.61033)$ \\
10 & 3.104505 & -0.400607 & 2.158206 \\
& $(0.89161)$ & $(0.19194)$ & $(0.66540)$ \\
\hline \hline
\end{tabular}

Canada

\begin{tabular}{ccrc}
\hline \hline Period & GRGDP & \multicolumn{1}{c}{ GINI } & \multicolumn{1}{c}{ NLB } \\
\hline \hline \multirow{2}{*}{2} & 2.972879 & -0.102210 & 1.909500 \\
& $(0.44289)$ & $(0.09874)$ & $(0.40101)$ \\
5 & 4.620791 & -0.126434 & 2.851661 \\
& $(1.32961)$ & $(0.18405)$ & $(1.09433)$ \\
10 & 5.216965 & -0.153955 & 3.108959 \\
& $(2.09012)$ & $(0.21050)$ & $(1.62067)$ \\
\hline \hline
\end{tabular}


Figure 3: IRFs to a Shock to Income Inequality

The UK

Responsesto a Cholesky One S.D. Innovation to GINI \pm 2 S.E.

GRGDP

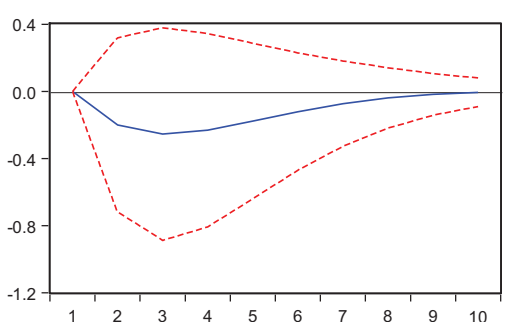

GIN

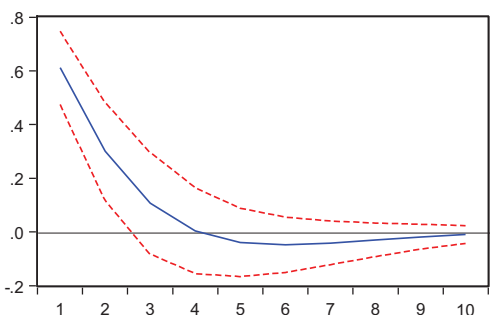

NLB

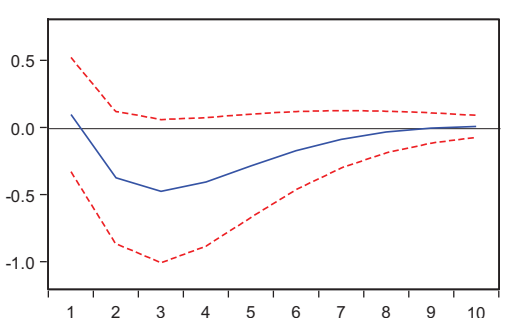

The USA

Responsesto a Cholesky One S.D. Innovation to $\mathrm{GINI} \pm 2$ S.E.

GRGDP

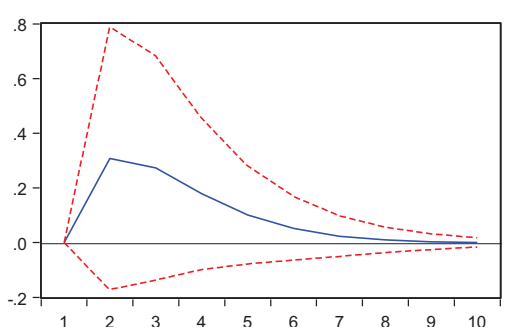

GINI

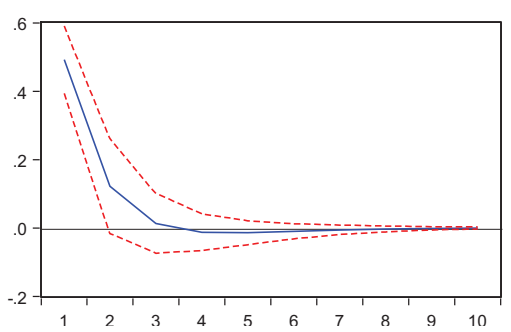

NLB

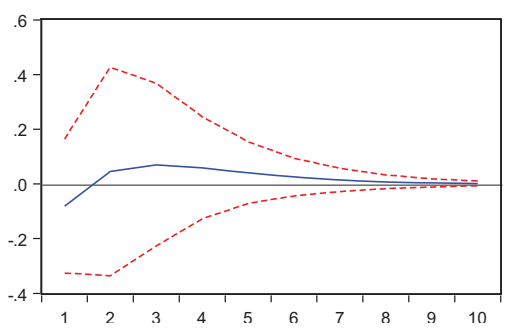

Canada

Responsesto a Cholesky One S.D. Innovation to GINI \pm 2 S.E.
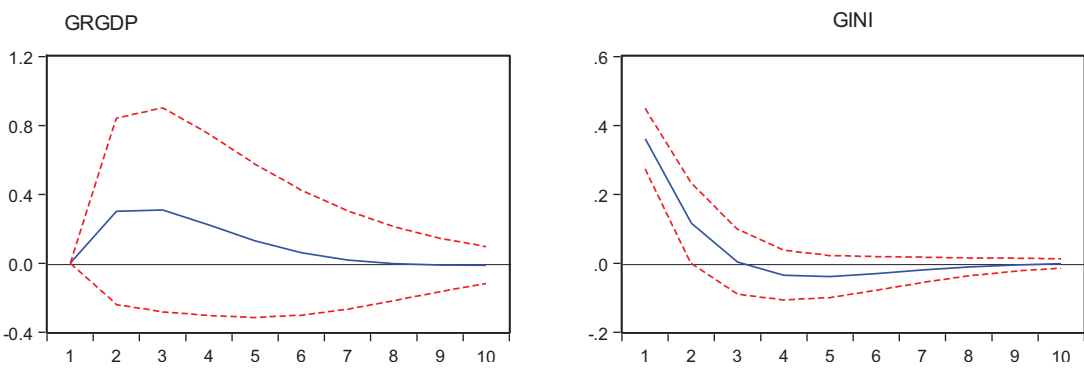

NLB

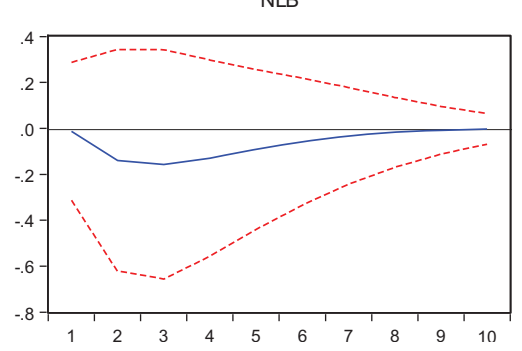


Table 4: Accumulated IRFs to a Shock to Income Inequality

The UK

\begin{tabular}{crcr}
\hline \hline Period & GRGDP & GINI & \multicolumn{1}{c}{ NLB } \\
\hline \hline \multirow{2}{*}{2} & -0.200601 & 0.911916 & -0.277761 \\
& $(0.25983)$ & $(0.13270)$ & $(0.40331)$ \\
5 & -0.866653 & 0.982657 & -1.442921 \\
& $(1.06062)$ & $(0.31587)$ & $(0.96317)$ \\
10 & -1.126364 & 0.834466 & -1.732700 \\
& $(1.36811)$ & $(0.35034)$ & $(1.10912)$ \\
\hline \hline
\end{tabular}

The USA

\begin{tabular}{cccc}
\hline \hline Period & GRGDP & GINI & NLB \\
\hline \hline \multirow{2}{*}{2} & 0.308058 & 0.614679 & -0.036112 \\
& $(0.23974)$ & $(0.09192)$ & $(0.25191)$ \\
5 & 0.859454 & 0.601057 & 0.133535 \\
& $(0.62547)$ & $(0.14703)$ & $(0.49332)$ \\
10 & 0.946704 & 0.579951 & 0.184220 \\
& $(0.66669)$ & $(0.14585)$ & $(0.51118)$ \\
\hline \hline
\end{tabular}

Canada

\begin{tabular}{cccc}
\hline \hline Period & GRGDP & GINI & \multicolumn{1}{c}{ NLB } \\
\hline \hline \multirow{2}{*}{2} & 0.300032 & 0.477469 & -0.152740 \\
& $(0.27035)$ & $(0.08117)$ & $(0.33494)$ \\
5 & 0.960148 & 0.406699 & -0.532545 \\
& $(0.98499)$ & $(0.14689)$ & $(0.87702)$ \\
10 & 1.011322 & 0.338410 & -0.653779 \\
& $(1.35914)$ & $(0.14498)$ & $(1.11158)$ \\
\hline \hline
\end{tabular}


Figure 4: Variance Decomposition - the UK

Variance Decomposition \pm 2 S.E.

Percent GRGDP variance due to GRGDP

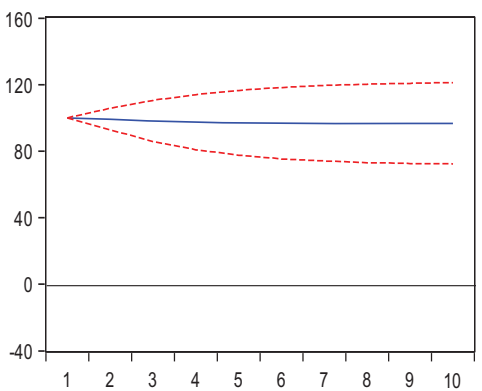

Percent GINI variance due to GRGDP

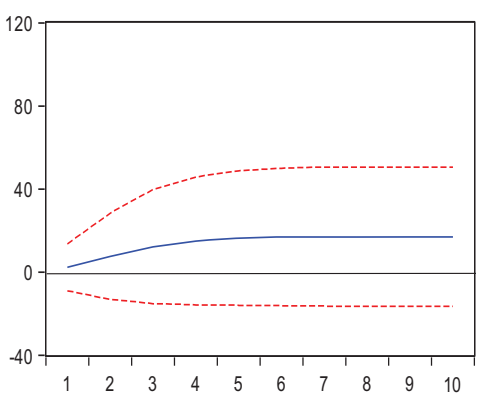

Percent NLB variance due to GRGDP

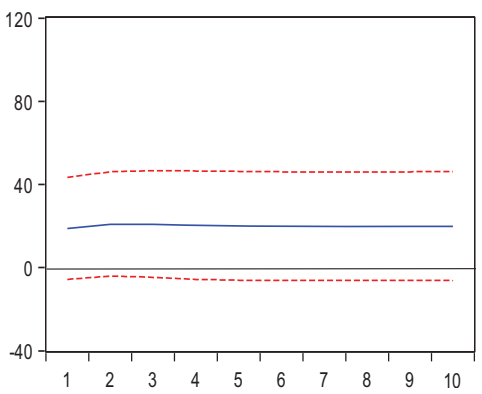

Percent GRGDP variance due to GINI

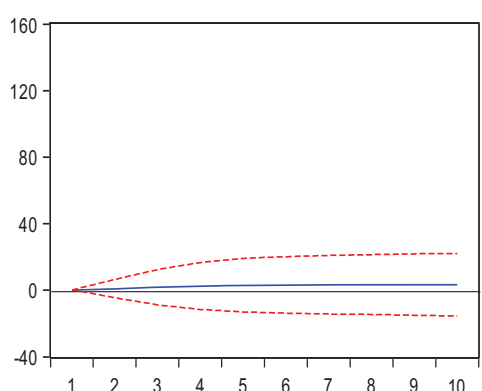

Percent GINI variance due to GINI

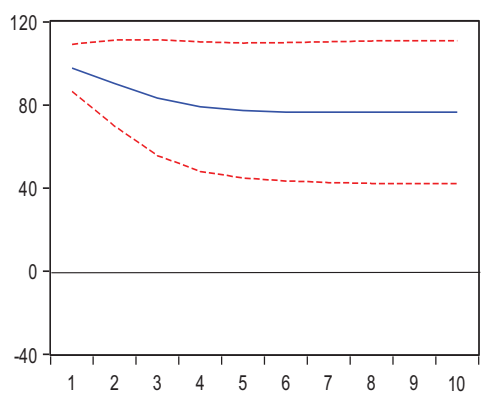

Percent NLB variance due to GIN

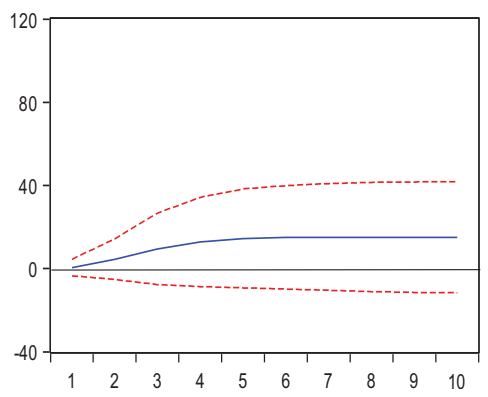

Percent GRGDP variance due to NLB

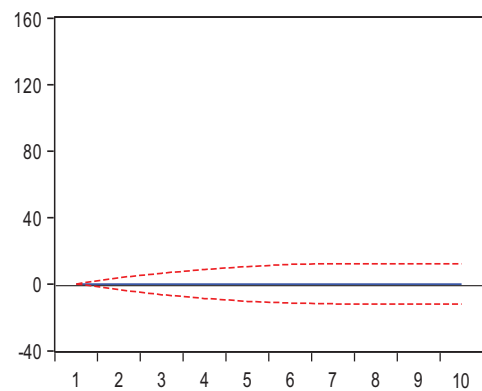

Percent GINI variance due to NLB

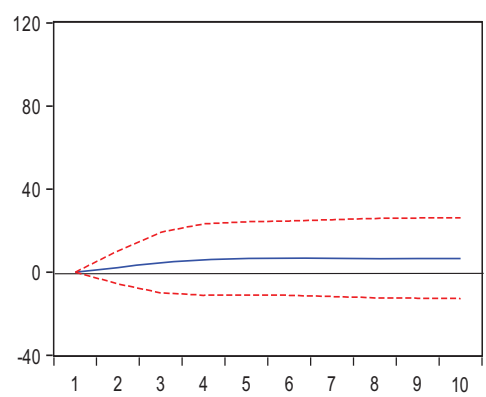

Percent NLB variance due to NLB

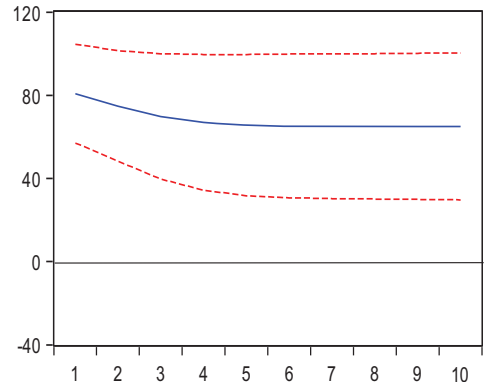


Figure 5: Variance Decomposition - the USA

Variance Decomposition \pm 2 S.E.

Percent GRGDP variance due to GRGDP

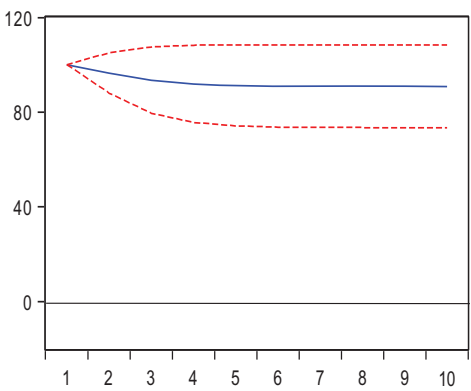

Percent GINI variance due to GRGDP

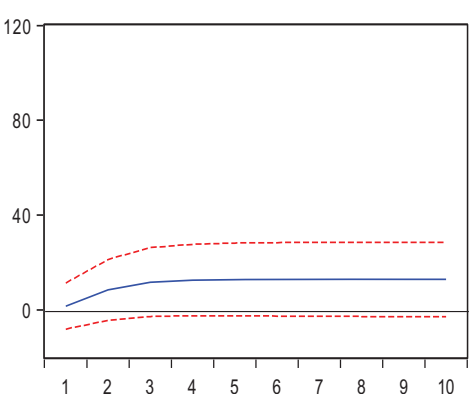

Percent NLB variance due to GRGDP

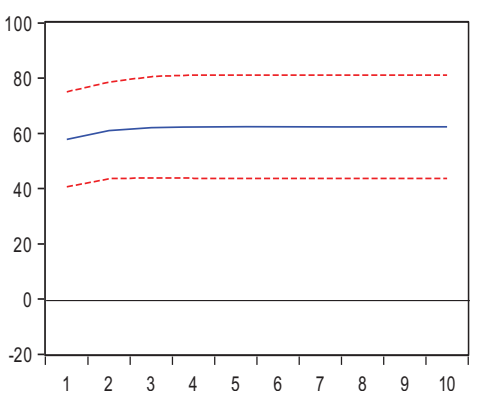

Percent GRGDP variance due to GINI

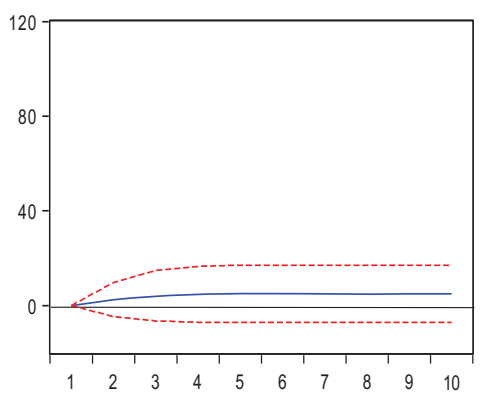

Percent GINI variance due to GINI

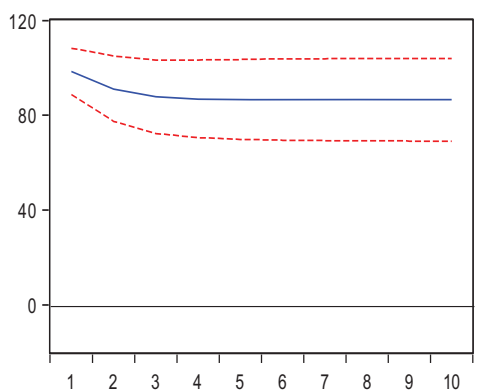

Percent NLB variance due to GINI

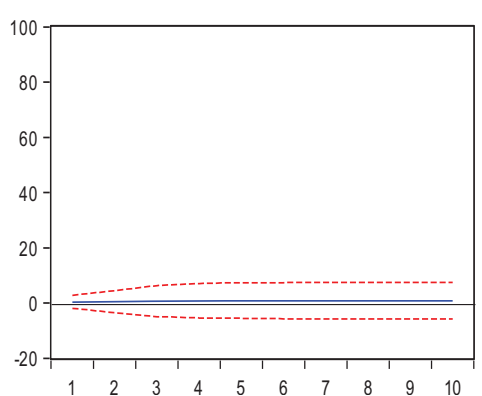

Percent GRGDP variance due to NLB

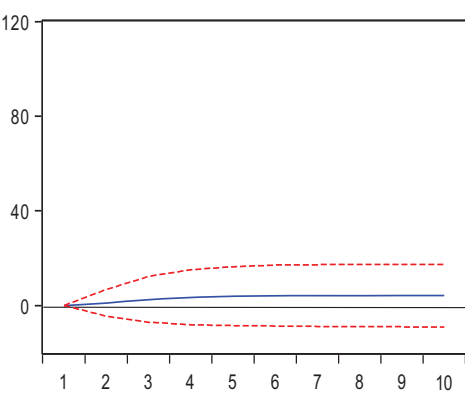

Percent GINI variance due to NLB

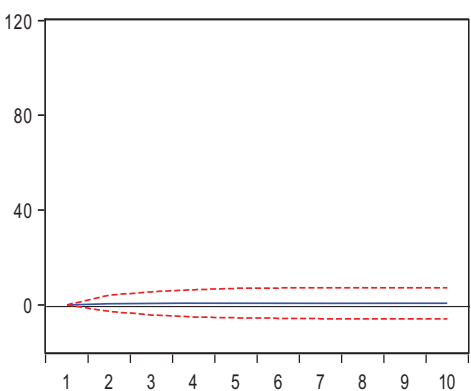

Percent NLB variance due to NLB

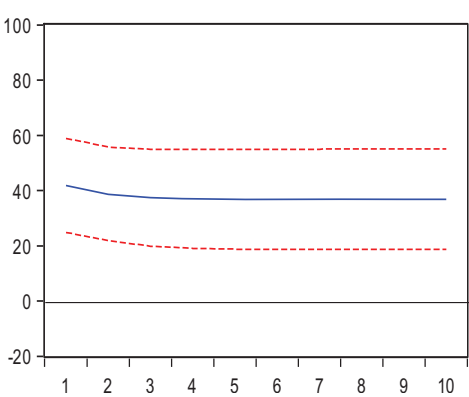


Figure 6: Variance Decomposition - Canada

Variance Decomposition \pm 2 S.E.

Percent GRGDP variance due to GRGDP

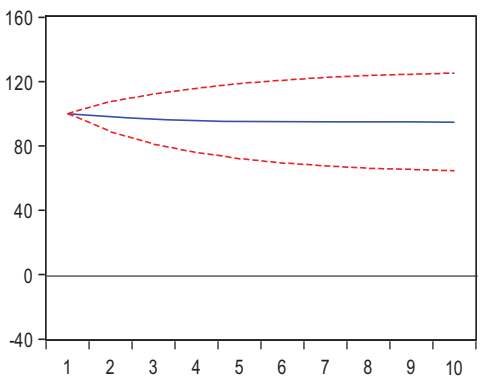

Percent GINI variance due to GRGDP

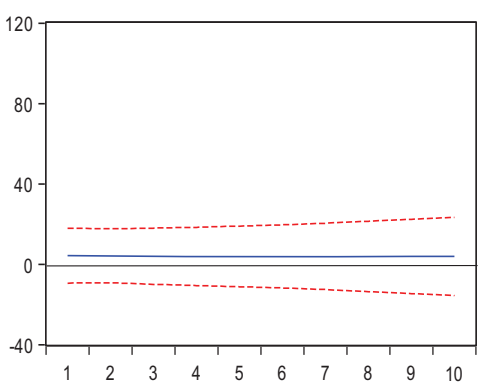

Percent NLB variance due to GRGDP

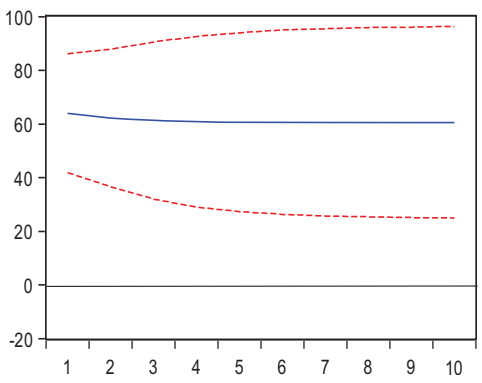

Percent GRGDP variance due to GINI

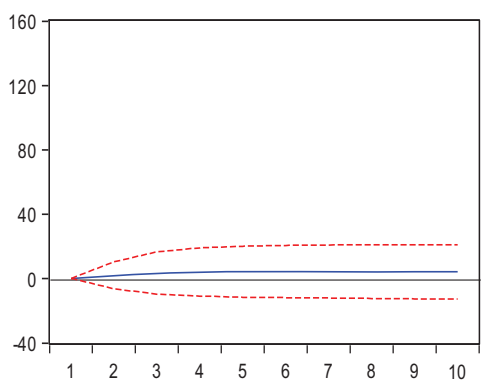

Percent GINI variance due to GIN

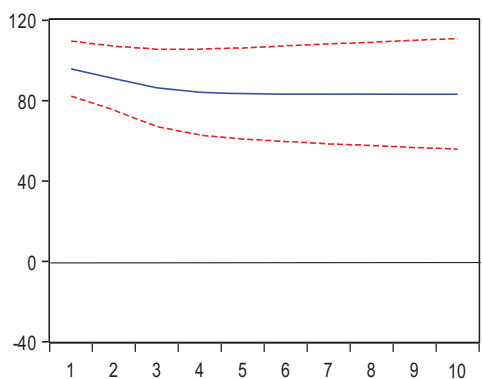

Percent NLB variance due to GIN

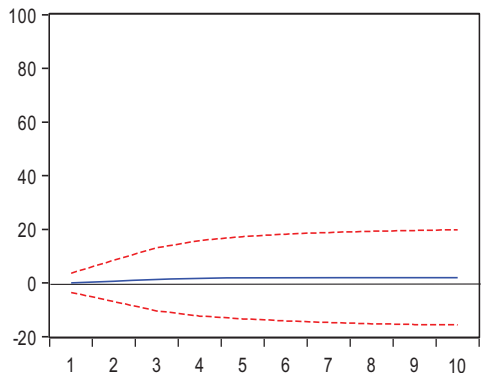

Percent GRGDP variance due to NLB

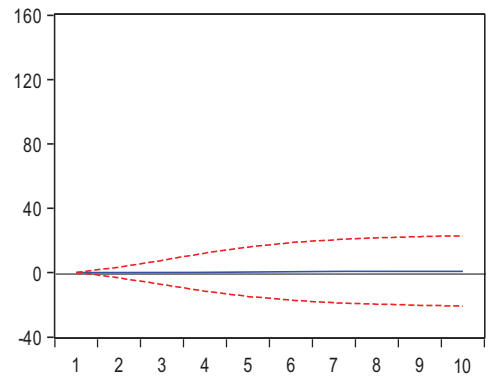

Percent GINI variance due to NLB

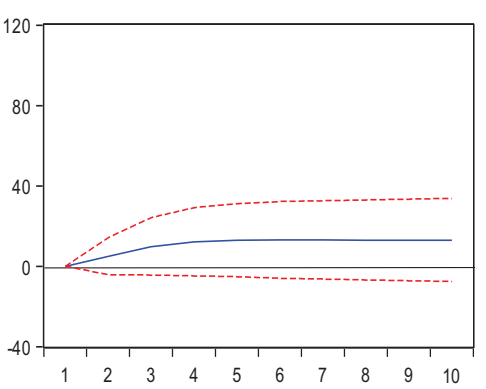

Percent NLB variance due to NLB

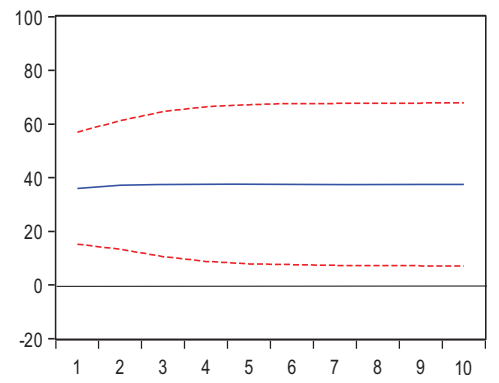




\section{The Extended VAR Model}

Figure 7: IRFs to a Shock to Government Spending

The UK

KG

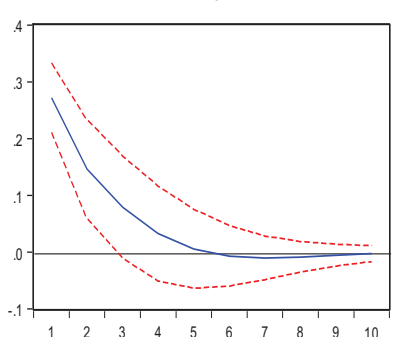

Responses to a Cholesky One S.D. Innovation to KG \pm 2 S.E.

GRGDP

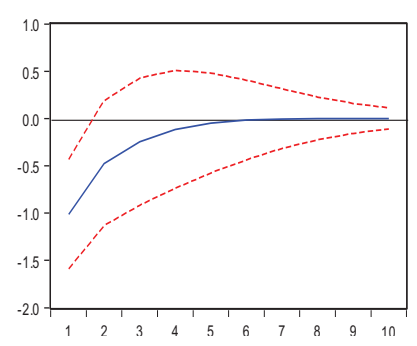

GINI

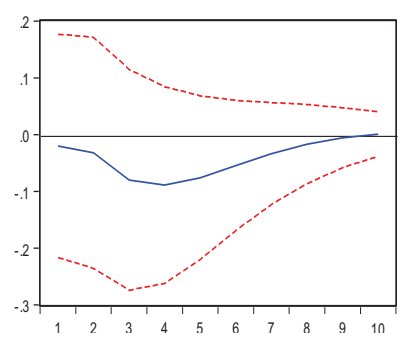

NLB

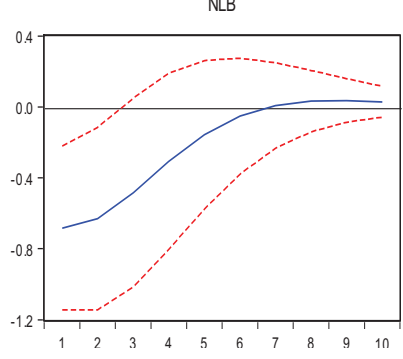

The USA

KG

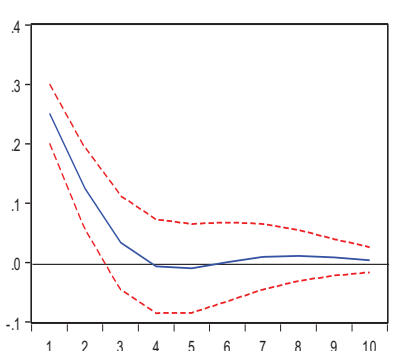

Responses to a Cholesky One S.D. Innovation to KG \pm 2 S.E.

GRGDP

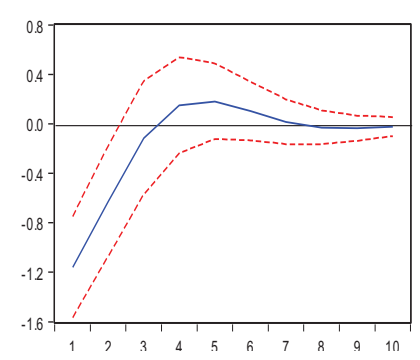

GIN

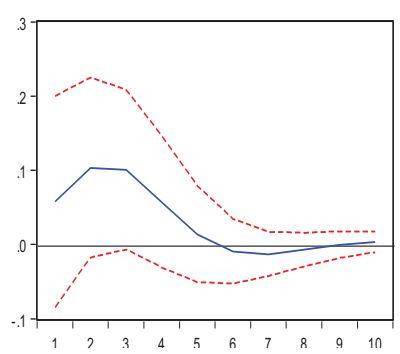

NLB

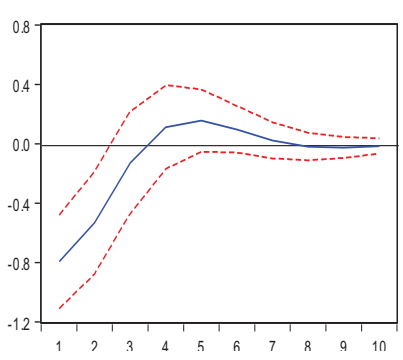

Canada

KG

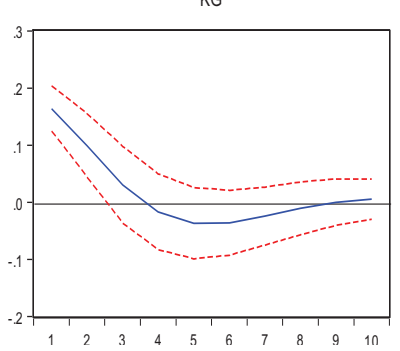

Responses to a Cholesky One S.D. Innovation to KG \pm 2 S.E.

GRGDP

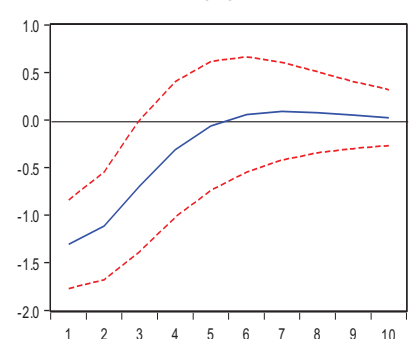

GINI

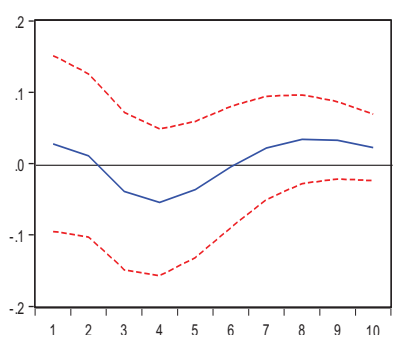

NLB

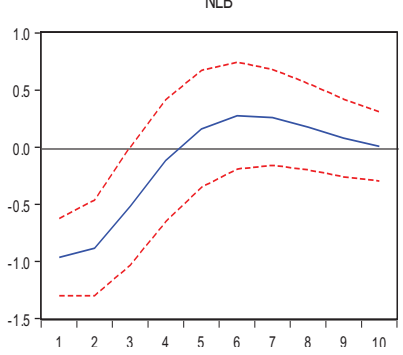


Table 5: Accumulated IRFs to a Shock to Government Spending

The UK

\begin{tabular}{ccccc}
\hline \hline Period & KG & GRGDP & GINI & NLB \\
\hline \hline \multirow{2}{*}{2} & 0.417666 & -1.485402 & -0.052830 & -1.313866 \\
& $(0.06177)$ & $(0.55348)$ & $(0.17218)$ & $(0.43066)$ \\
5 & 0.533503 & -1.898001 & -0.298869 & -2.263642 \\
& $(0.16025)$ & $(1.32147)$ & $(0.35336)$ & $(0.98767)$ \\
10 & 0.497455 & -1.921926 & -0.410602 & -2.214989 \\
& $(0.19119)$ & $(1.77646)$ & $(0.40276)$ & $(1.17329)$ \\
\hline \hline
\end{tabular}

The USA

\begin{tabular}{ccccc}
\hline \hline Period & KG & GRGDP & GINI & NLB \\
\hline \hline \multirow{2}{*}{2} & 0.375167 & -1.788564 & 0.160961 & -1.328694 \\
& $(0.04922)$ & $(0.37326)$ & $(0.10611)$ & $(0.28390)$ \\
5 & 0.390764 & -1.572154 & 0.332754 & -1.192997 \\
& $(0.13417)$ & $(0.69904)$ & $(0.18053)$ & $(0.50238)$ \\
10 & 0.423655 & -1.544327 & 0.305872 & -1.144199 \\
& $(0.20065)$ & $(0.59874)$ & $(0.17540)$ & $(0.44023)$ \\
\hline \hline
\end{tabular}

Canada

\begin{tabular}{ccccc}
\hline \hline Period & KG & GRGDP & GINI & NLB \\
\hline \hline \multirow{2}{*}{2} & 0.262953 & -2.423162 & 0.038953 & -1.849514 \\
& $(0.04060)$ & $(0.44775)$ & $(0.09688)$ & $(0.32289)$ \\
5 & 0.238700 & -3.491493 & -0.090864 & -2.328222 \\
& $(0.10663)$ & $(1.18169)$ & $(0.17705)$ & $(0.83422)$ \\
10 & 0.170885 & -3.189625 & 0.015043 & -1.540005 \\
& $(0.09300)$ & $(1.35129)$ & $(0.18425)$ & $(0.78118)$ \\
\hline \hline
\end{tabular}


Figure 8: IRFs to a Shock to Investment

The UK

$\mathrm{KI}$

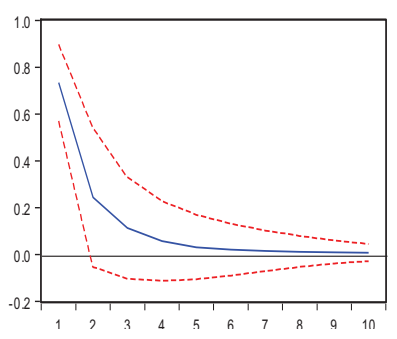

The USA

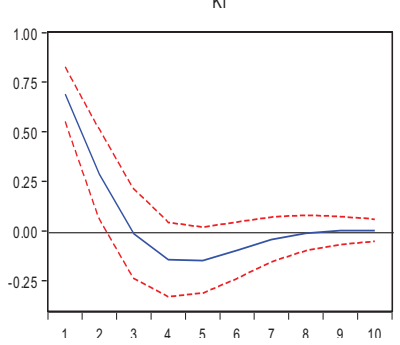

Canada

KI

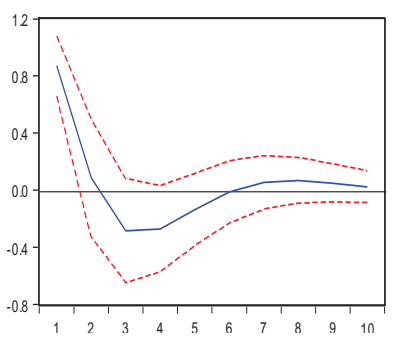

Responses to a Cholesky One S.D. Innovation to KI \pm 2 S.E.

GRGDP

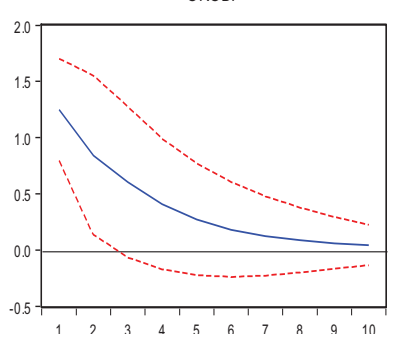

Responses to a Cholesky One S.D. Innovation to KI +2S.E.
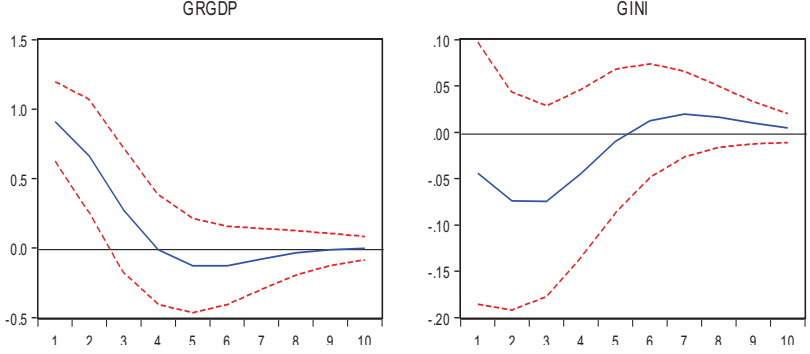

NLB

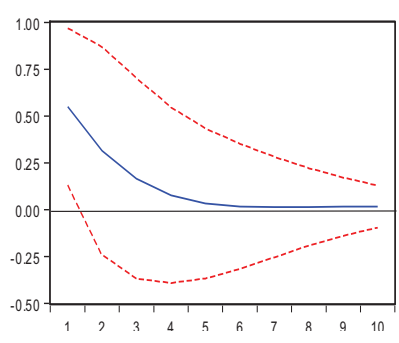

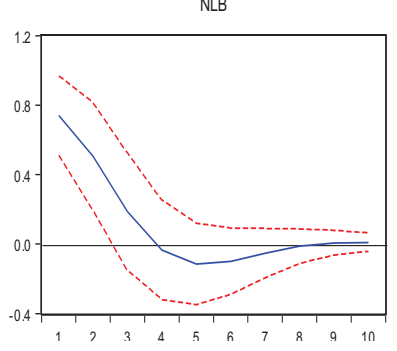

Responses to a CholeskyOne S.D. Innovation to KI \pm 2 S.E.

GRGDP

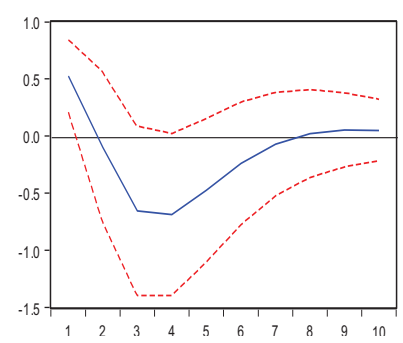

GINI

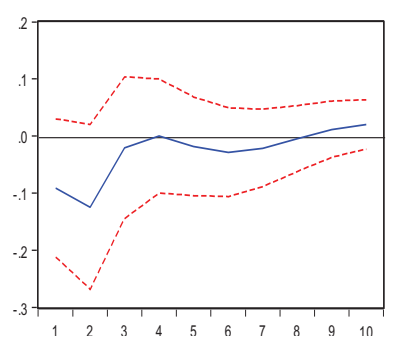

NLB

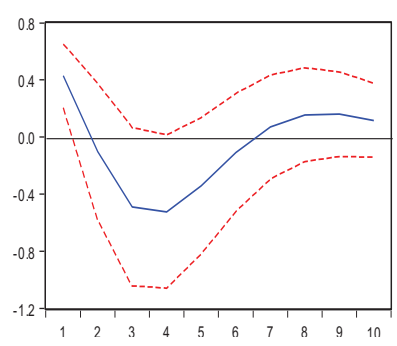


Table 6: Accumulated IRFs to a Shock to Investment

The UK

\begin{tabular}{ccccc}
\hline \hline Period & KI & GRGDP & GINI & NLB \\
\hline \hline \multirow{2}{*}{2} & 0.976506 & 2.089991 & 0.137088 & 0.861668 \\
& $(0.18238)$ & $(0.50155)$ & $(0.17924)$ & $(0.41400)$ \\
5 & 1.175426 & 3.371113 & 0.436451 & 1.133473 \\
& $(0.38343)$ & $(1.24859)$ & $(0.34691)$ & $(0.94564)$ \\
10 & 1.237162 & 3.863084 & 0.526875 & 1.205034 \\
& $(0.48539)$ & $(1.78924)$ & $(0.41741)$ & $(1.20199)$ \\
\hline \hline
\end{tabular}

The USA

\begin{tabular}{ccccc}
\hline \hline Period & KI & \multicolumn{1}{c}{ GRGDP } & \multicolumn{1}{c}{ GINI } & \multicolumn{1}{c}{ NLB } \\
\hline \hline \multirow{2}{*}{2} & 0.977815 & 1.570977 & -0.118366 & 1.246275 \\
& $(0.14694)$ & $(0.28641)$ & $(0.10394)$ & $(0.21694)$ \\
5 & 0.672366 & 1.702047 & -0.247252 & 1.283709 \\
& $(0.31724)$ & $(0.69246)$ & $(0.18463)$ & $(0.49642)$ \\
10 & 0.527968 & 1.446287 & -0.184698 & 1.132109 \\
& $(0.30665)$ & $(0.72930)$ & $(0.21347)$ & $(0.52630)$ \\
\hline \hline
\end{tabular}

Canada

\begin{tabular}{ccrrr}
\hline \hline Period & KI & \multicolumn{1}{c}{ GRGDP } & \multicolumn{1}{c}{ GINI } & \multicolumn{1}{c}{ NLB } \\
\hline \hline \multirow{2}{*}{2} & 0.955923 & 0.423136 & -0.216128 & 0.325310 \\
& $(0.23754)$ & $(0.39695)$ & $(0.10431)$ & $(0.27751)$ \\
5 & 0.258630 & -1.397022 & -0.254878 & -1.030792 \\
& $(0.44941)$ & $(1.16279)$ & $(0.17887)$ & $(0.82390)$ \\
10 & 0.435789 & -1.585301 & -0.277969 & -0.639629 \\
& $(0.40812)$ & $(1.42195)$ & $(0.20039)$ & $(0.82961)$ \\
\hline \hline
\end{tabular}


Figure 9: IRFs to a Shock to Taxes

The UK
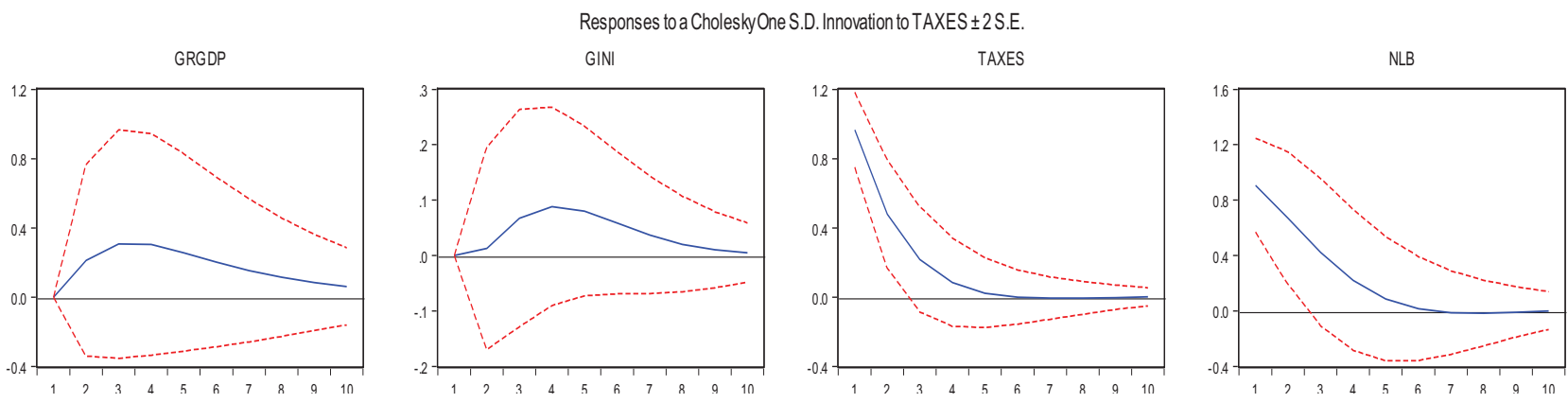

The USA
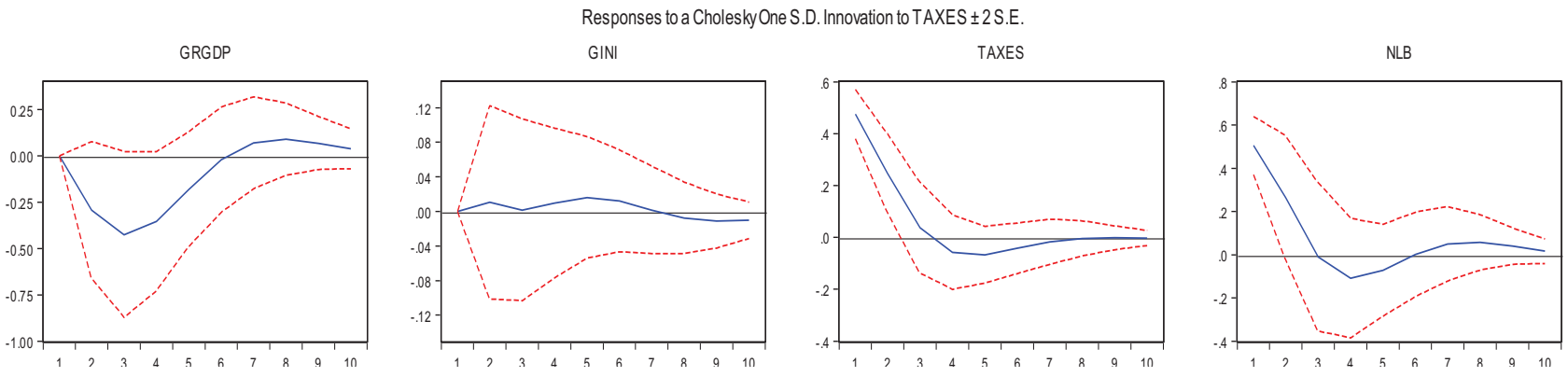

\section{Canada}

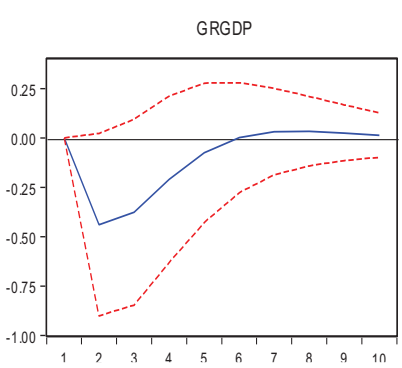

Responses to a CholeskyOne S.D. Innovation to TAXES \pm 2 S.E.

GIN

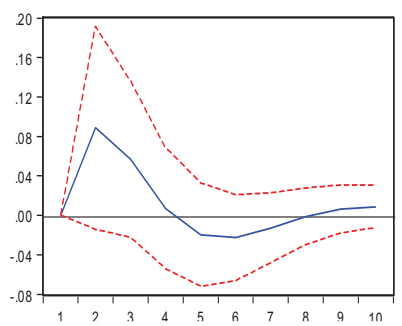

TAXES

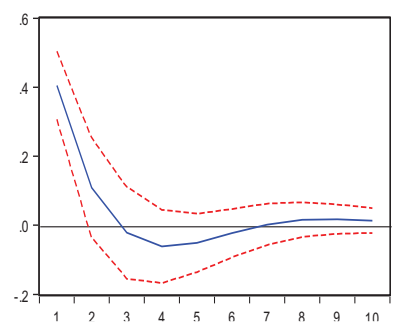

NLB

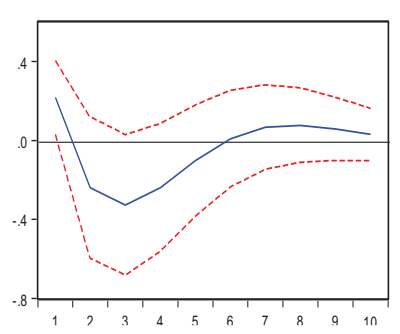


Table 7: Accumulated IRFs to a Shock to Taxes

The UK

\begin{tabular}{ccccc}
\hline \hline Period & GRGDP & GINI & TAXES & NLB \\
\hline \hline \multirow{2}{*}{2} & 0.211298 & 0.012955 & 1.445778 & 1.575266 \\
& $(0.27662)$ & $(0.09138)$ & $(0.21860)$ & $(0.34619)$ \\
& $(0.90196)$ & $(0.26417)$ & $(0.45524)$ & $(0.77530)$ \\
5 & 1.076333 & 0.248470 & 1.769396 & 2.303731 \\
& $(1.16556)$ & $(0.32564)$ & $(0.53597)$ & $(0.95182)$ \\
10 & 1.686528 & 0.378987 & 1.752405 & 2.277884 \\
& $(1.90557)$ & $(0.44835)$ & $(0.69333)$ & $(1.33621)$ \\
\hline \hline
\end{tabular}

The USA

\begin{tabular}{crccc}
\hline \hline Period & GRGDP & GINI & TAXES & NLB \\
\hline \hline \multirow{2}{*}{2} & -0.293404 & 0.010387 & 0.722265 & 0.767783 \\
& $(0.18450)$ & $(0.05602)$ & $(0.10190)$ & $(0.15591)$ \\
5 & -1.251813 & 0.037928 & 0.633081 & 0.576080 \\
& $(0.62556)$ & $(0.15491)$ & $(0.24720)$ & $(0.45646)$ \\
10 & -1.007516 & 0.022178 & 0.563050 & 0.737884 \\
& $(0.60279)$ & $(0.16656)$ & $(0.23440)$ & $(0.43322)$ \\
\hline \hline
\end{tabular}

Canada

\begin{tabular}{crcrr}
\hline \hline Period & GRGDP & GINI & TAXES & \multicolumn{1}{c}{ NLB } \\
\hline \hline \multirow{2}{*}{2} & -0.440329 & 0.088826 & 0.514448 & -0.021416 \\
& $(0.23117)$ & $(0.05150)$ & $(0.09482)$ & $(0.22563)$ \\
5 & -1.101992 & 0.132925 & 0.378692 & -0.690103 \\
& $(0.67492)$ & $(0.09885)$ & $(0.16651)$ & $(0.50037)$ \\
10 & -0.995582 & 0.111192 & 0.403685 & -0.450146 \\
& $(0.61523)$ & $(0.08789)$ & $(0.14412)$ & $(0.34460)$ \\
\hline \hline
\end{tabular}


Figure 10: Variance Decomposition - the UK
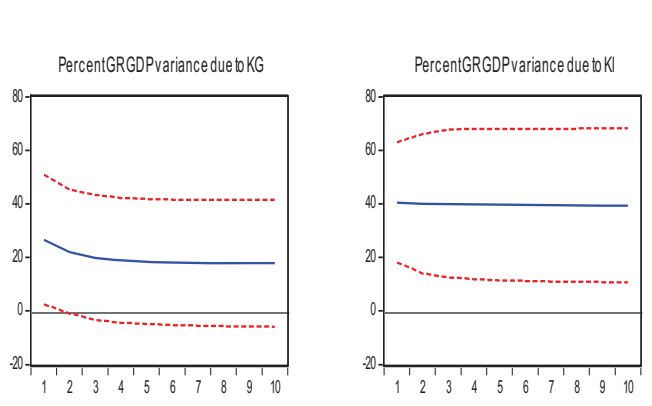

Vaniance Decomposition $\pm 2 S$.E.

PercentGRGDPvariance due to GRGDP
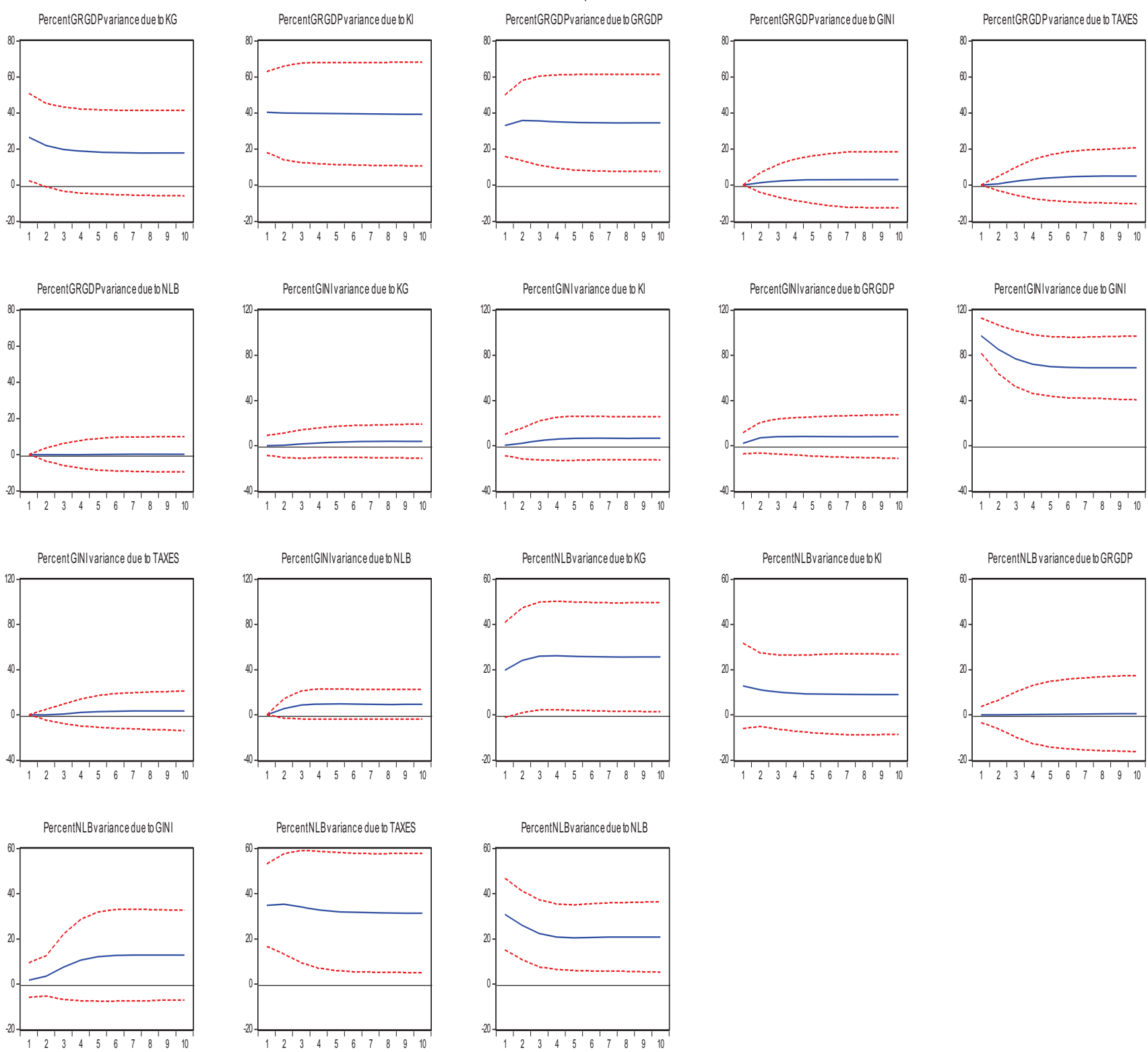
Figure 11: Variance Decomposition - the USA
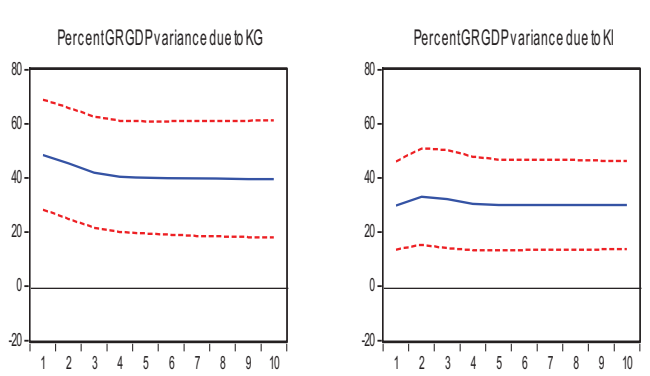

Vaniance Decomposition \pm 2 S.E.

PercentGRGDPvariance due to GRGDP

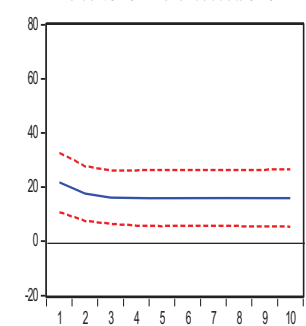

PercentGRGDPvariance due to GINI

PercentGRGDPvariance due to TAXES
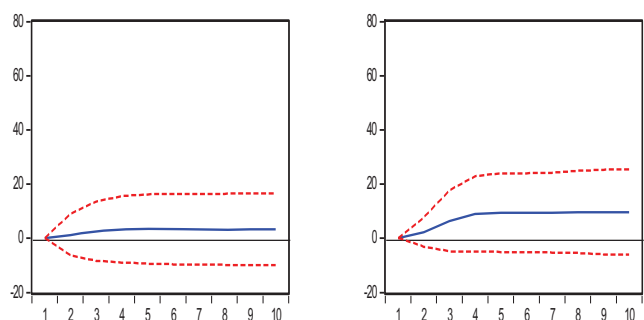

PercentGRGDPvariancedue toNLB
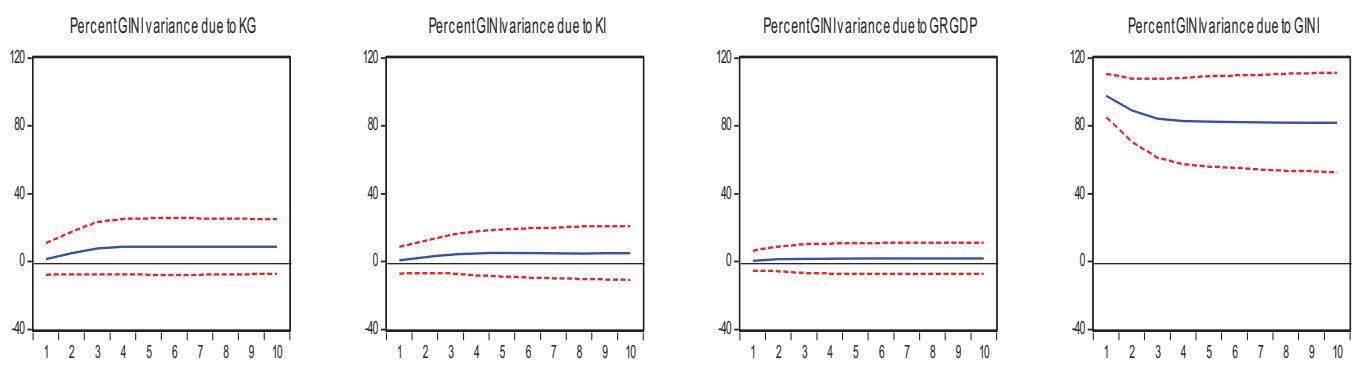

PercentGINvariance due to TAXES
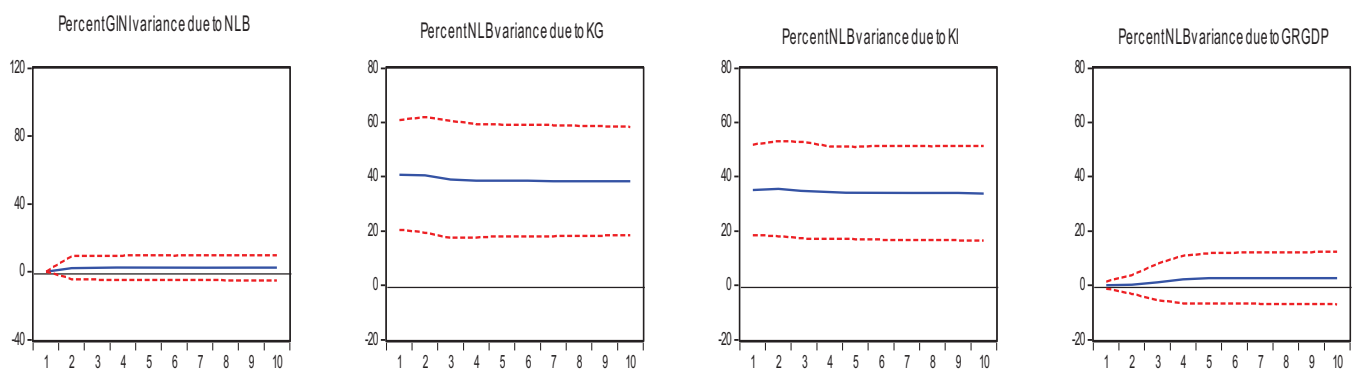

PercentNLBvariance due to GINL
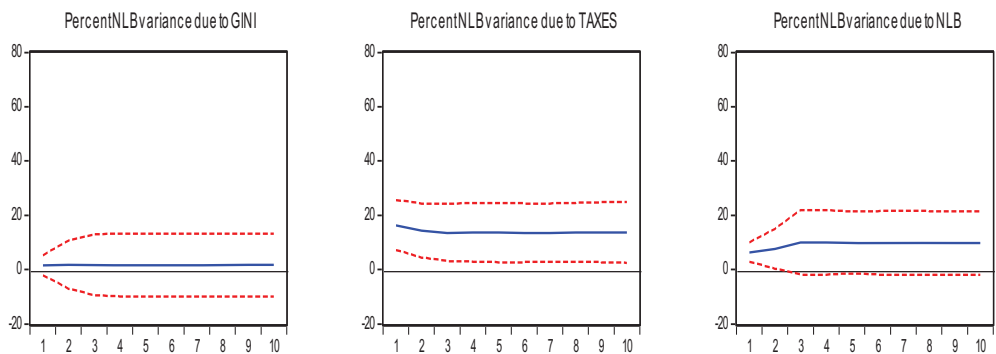


\section{Figure 12: Variance Decomposition - Canada}
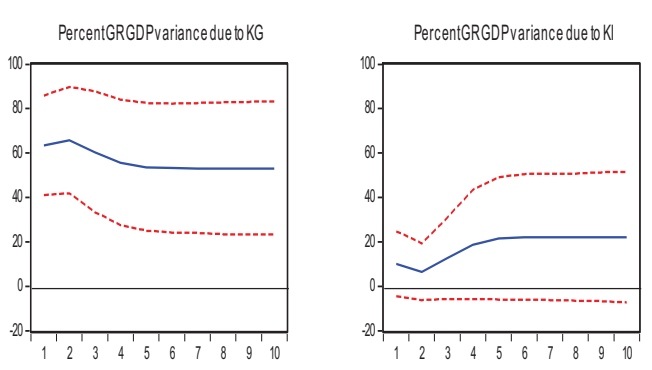

Variance Decomposition $\pm 2 S$.E.

PercentGRGDPvariance due to GRGDP
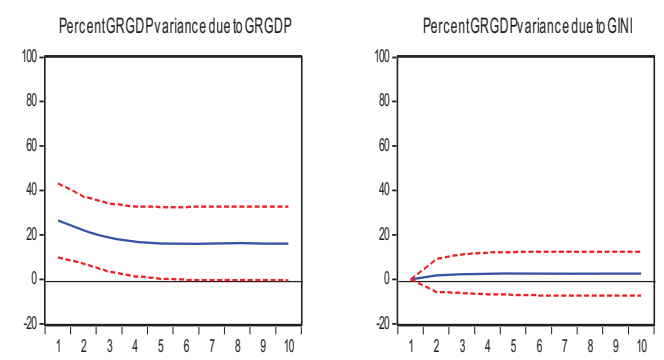

PercentGRGDPvariance due to TAXES
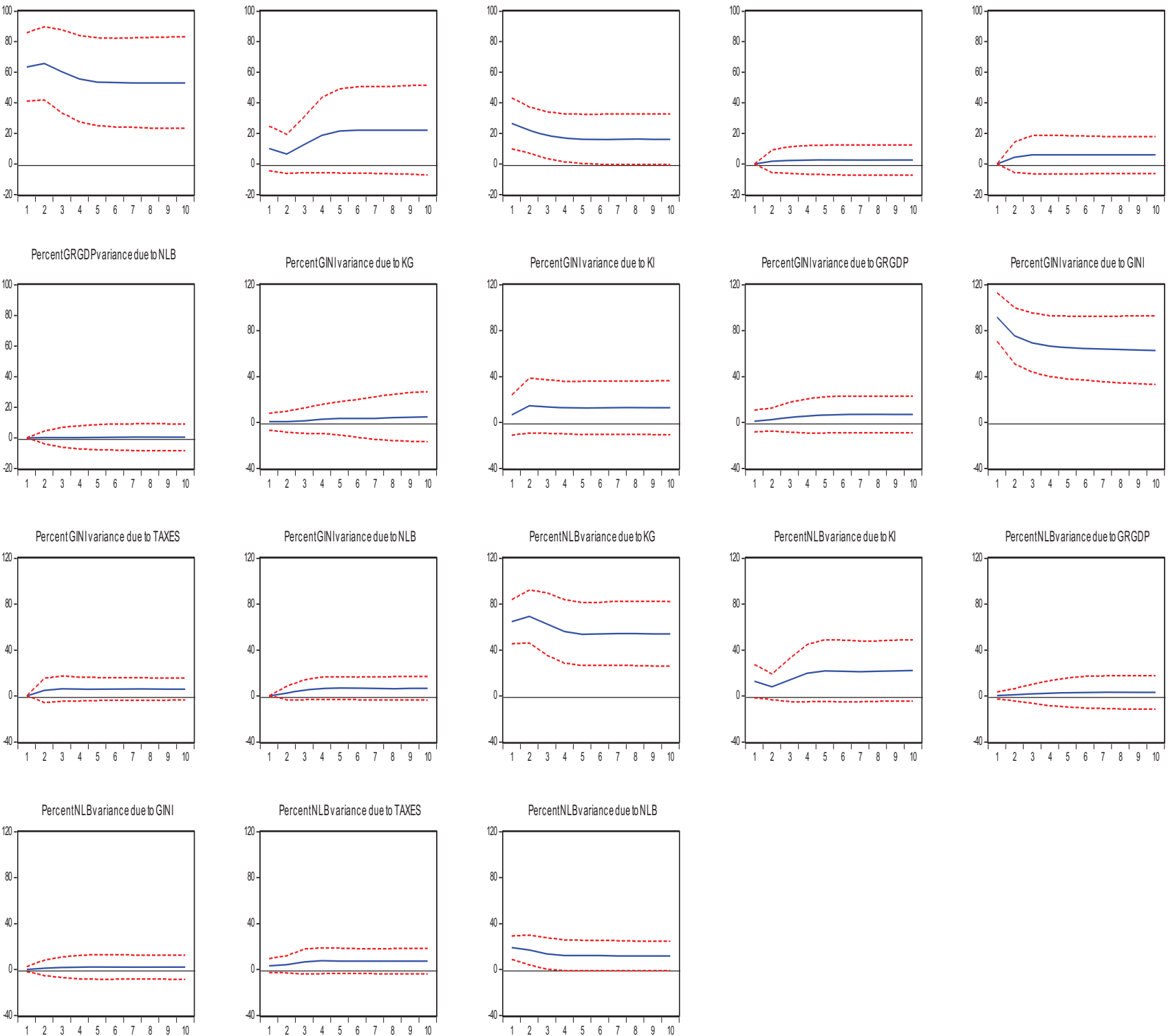
